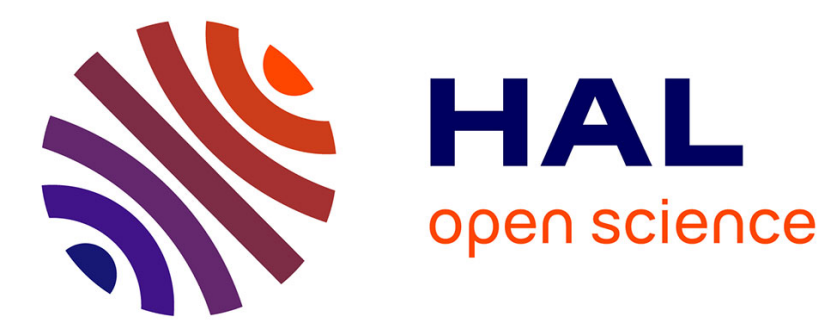

\title{
Expropriation risk vs. government bailout: implications for minority shareholders of state-owned banks
}

\author{
Aldy Fariz Achsanta, Laetitia Lepetit, Amine Tarazi
}

\section{To cite this version:}

Aldy Fariz Achsanta, Laetitia Lepetit, Amine Tarazi. Expropriation risk vs. government bailout: implications for minority shareholders of state-owned banks. 2020. hal-02512308

\section{HAL Id: hal-02512308 \\ https://hal-unilim.archives-ouvertes.fr/hal-02512308}

Preprint submitted on 19 Mar 2020

HAL is a multi-disciplinary open access archive for the deposit and dissemination of scientific research documents, whether they are published or not. The documents may come from teaching and research institutions in France or abroad, or from public or private research centers.
L'archive ouverte pluridisciplinaire HAL, est destinée au dépôt et à la diffusion de documents scientifiques de niveau recherche, publiés ou non, émanant des établissements d'enseignement et de recherche français ou étrangers, des laboratoires publics ou privés. 


\title{
Expropriation risk vs. government bailout: implications for minority shareholders of state-owned banks
}

\author{
Aldy Fariz Achsanta ${ }^{\mathrm{a} 1}$, Laetitia Lepetit ${ }^{\mathrm{a}}$, Amine Tarazi $^{\mathrm{a}, \mathrm{b}}$ \\ a Université de Limoges, LAPE, 5 rue Félix Eboué, 87031 Limoges Cedex, France \\ ${ }^{b}$ Institut Universitaire de France (IUF), 1 rue Descartes, 75231 Paris Cedex 05, France
}

This version : March 18, 2020

\begin{abstract}
We investigate the implications of government versus private ownership for bank minority shareholders. Specifically, we use unique data to examine whether the stock prices of government-owned and family-owned banks, equally engaged in related lending, differently react to loan announcements. Our empirical findings show that the expected negative market reaction due to minority shareholder expropriation driven by related lending ("grabbing hand" effect), is offset by shareholders' expectations of future support from the government ("helping hand" effect). Positive announcement returns are also larger for new loans to state-owned firms than for those to private firms. Our findings support the view that in countries with weak shareholder protection, shareholders of state-owned banks rationally anticipate expropriation, but are willing to accept it in exchange for higher expectations of government support to stateowned banks and to state-owned firms.
\end{abstract}

JEL Classification: G21, G28

Keywords: Banks; government ownership; loan announcements; related party transactions.

\footnotetext{
${ }^{1}$ Corresponding author: A. Fariz Achsanta: aldy-fariz.achsanta@unilim.fr.
} 


\section{Introduction}

In emerging countries, although many banks have been privatized over the last twenty years, governments still maintain their controlling shareholding positions in many privately-owned but also publicly-traded banks. Conversely, in developed countries, the bank failures triggered by the 2007-2008 global financial crisis have led governments to substantially increase their stakes and involvement in several large banks. How government ownership influences banks' corporate governance has, therefore, become an important area of research for developed as well as emerging economies.

According to the "grabbing hand" hypothesis of Frye and Shleifer (1997) and Shleifer and Vishny (1998), government ownership might be harmful to corporate governance if the state expropriates shareholders' wealth for the benefit of politicians. In line with this hypothesis, La Porta et al. (2002), Dinc (2005), Sapienza (2004) and Khwaja and Mian (2005) find that government ownership of banks facilitates the financing of projects that maximize the private welfare of politicians rather than banks' revenues. Meanwhile, the "helping hand" hypothesis argues that the state as a shareholder is in a position to provide preferential treatment and is unlikely to let down large state-owned firms in case of distress (Faccio et al., 2006). Consequently, the interests of minority shareholders of state-owned banks are potentially influenced by two countervailing effects. Indeed, although they can suffer from expropriation, shareholders might also benefit from taxpayer support to either state-owned firms or the stateowned banks themselves. The research question that we address in this paper is how minority shareholders anticipate being affected by government ownership when banks extend their activities. On the one hand, as the bank invests in new projects, minority shareholders will expect higher expropriation ("grabbing hand" effect). On the other hand, if these new projects fail, they will expect specific support from taxpayers and to a larger extent than shareholders of private banks would ("helping hand" effect).

To compare the relative merits and disadvantages of state versus private ownership previous studies have essentially focused on non-financial firms. Claessens et al. (1998) find, for a sample of publicly listed East Asian firms, that government ownership does not significantly influence market valuation. They also find that firms controlled by families exhibit lower market values. Their findings hence indicate that minority shareholders suffer from expropriation to a larger extent in such firms than in state-owned firms. Conversely, using a sample of listed non-financial Chinese firms, Bai et al. (2004) find that large holdings by the government have a negative effect on market valuation. Cheung et al. (2009) further find that the "grabbing hand" hypothesis only holds for Chinese firms controlled by local governments, 
while central government ownership is beneficial for minority shareholders in line with the "helping hand" hypothesis.

In this paper, we focus on banking firms and investigate the valuation effect of loan announcements in publicly listed state-owned banks (SOBs) in comparison to publicly listed non-state-owned banks and by specifically considering the type of borrowing firms (stateowned firms or non-state-owned firms). Looking at banks and not firms from the real sector brings in an important dimension that has not been investigated so far. Government bailouts are much more common for banks than other firms and hence while shareholders might expect a lower return from these new projects because of expropriation, they might also perceive them as less risky because of the higher probability of government support in case of distress. Unless default resolution mechanisms are credibly implemented to impose the losses on majority as well as minority shareholders in both government and private banks (bail-in and not bailout), such behavior could be even more pronounced in the post 2007-2008 financial crisis era.

We use an event study approach to investigate the market reaction to bank loan announcements for state-owned in comparison to private. Specifically, to uncover the possible presence of a "helping hand" effect for state-owned banks we look at how the extent of expropriation affects the stock price reaction in both types of banks. To thoroughly conduct our empirical investigation, we focus on a single country, Indonesia, whose banking industry provides an ideal setting. Firstly, since 2009, a regulation has required listed Indonesian firms to report information on related party transactions in their annual report. This allows us to consider related party transactions, and more specifically related lending, as a proxy of the extent of expropriation. Secondly, the Indonesian banking sector is characterized by strong government ownership. The banking reforms implemented in the 2000s, especially with the Single Presence Policy Act of 2006, strengthen the presence of the government as a controlling shareholder but also force private investors to consolidate their ownership to maintain their control. This leads to a high concentration of ownership in the banking sector, with either the government or families being the controlling shareholder in a large number of banks. Thirdly, according to the World Bank Doing Business Index, Indonesia is ranked 88th regarding the protection of minority investors, far behind its neighboring countries such as Singapore (1st), Malaysia (4th), and Thailand (36th). The combination of high ownership concentration and weak minority shareholder protections is likely to favor the expropriation of minority shareholders. The existing literature shows that families and government, as controlling shareholders, are more prone to engage in the extraction of corporate resources through perks or transfer of assets on non-market terms to related parties (Claessens et al., 2002; Villalonga 
and Amit, 2006). We, therefore, use family-owned banks as a benchmark against which to assess the valuation effect of loan announcements for state-owned banks under the threat of expropriation. If investors rationally anticipate the "helping hand" effect to mitigate the "grabbing hand" effect, we should expect announcement returns of state-owned banks to be less affected than those of family-owned banks for similar levels of expropriation.

We further investigate if the valuation effect of loan announcements from state-owned banks or family-owned banks could also depend on the type of borrowers they lend to. When the borrower is a state-owned firm (SOE), minority shareholders of state-owned banks could anticipate benefiting from a twin "helping hand" effect as SOEs are also likely to benefit from government support in case of distress. Similarly, minority shareholders of family-owned banks could also benefit from a "helping hand" effect if the loan is made to a SOE.

We use a unique hand-collected dataset on 342 loan announcements of listed Indonesian banks. The dataset includes information on the ownership structure of banks and borrowing firms as well as information on banks' related party transactions to proxy the likelihood of expropriation over the 2009-2014 period. Reliable data on related party transactions are only available since 2009, as explained above. We do not consider data beyond 2014 because a specific regulation for banks implied many changes in the ownership structure of banks after 2014. The new rules limit the shares held by financial institutions, non-financial institutions, and individuals/families to $40 \%, 30 \%$, and $20 \%$, respectively.

Our findings show that there is no significant relationship between announcement returns and expropriation at state-owned banks, while there is a negative and significant relationship at family-owned banks. Our results further show that, for state-owned banks, announcement returns become significantly and positively associated with expropriation when loans are granted to state-owned firms. Taken altogether these results are consistent with the conjecture that even if expropriation is present in state-owned banks ("grabbing hand" effect), the negative outcome for stock prices of such resource diversion is likely to be offset by the "helping hand" effect (when loans are extended to privately-owned firms), and even to be outweighed by the twin "helping hand" effect (when loans are extended to state-owned firms).

This study makes several contributions to the literature. Firstly, it contributes to the literature on state versus private ownership, providing evidence that for dispersed minority shareholders government ownership of banks can be more beneficial than private ownership, especially when the institutional environment is weak. Secondly, it examines the value of government ownership of banks and sheds light on yet undocumented factors that make bank stock prices react to loan 
announcements. Our findings are of interest to policymakers in countries with weak legal protection for shareholders and where governments maintain their controlling shareholdings.

The rest of the paper is organized as follows. Section 2 presents the related literature and the tested hypotheses. Section 3 describes our sample and defines our variables of interest. Section 4 presents the market reaction results. Section 5 examines the determinants of bank loan announcements. Section 6 contains additional investigations. Section 7 presents robustness checks, and section 8 concludes the paper.

\section{Background and hypotheses}

Megginson (2005) argues that state ownership of banks is driven by several factors. Firstly, government ownership of banks is a way to maintain domestic control over a nation's financial system. Secondly, state-owned banks can compensate for a possible lack of private capital with sufficient risk tolerance to finance growth. Thirdly, state-owned banks can be used to finance sectors which play an important social role and which private banks would be less keen to finance because of lower profitability than other sectors. Globally, state-owned banks are also expected to lend countercyclically, providing credit when and where other banks do not. This could encourage industrialization and development at a more rapid pace than private financing would allow.

Controlling government shareholders are therefore more likely to adopt a non-profit maximization behavior to achieve social and political objectives, to the detriment of other shareholders' interest (Bai et al., 2000; Lin and Li, 2008). Schleifer and Vishny (1994) show that, even in a fully competitive market, state-owned firms will be inefficient because the state forces them to pursue non-economic objectives, such as maintaining employment. Shleifer and Vishny (1998) argue that this "grabbing hand" behavior, with governments expropriating shareholders' wealth from state-owned firms, implies that private ownership is preferable to state ownership. In line with this argument, empirical evidence shows that government ownership of banks is detrimental to their performance (Berger et al, 2005; Bonin et al., 2005; Berger et al, 2009). ${ }^{2}$

However, prior research has also shown that shareholders in state-owned firms may benefit from government cross-subsidization to counter financial difficulties. Seshinski and LopezCalva (2003) document that governments provide subsidies to state-owned firms in financial distress whenever the political costs of allowing these firms to go bankrupt outweigh the

\footnotetext{
${ }^{2}$ See the survey of Shaban and James (2018).
} 
political cost of subsidization. The large number of bailouts during the global financial crisis of 2007-2008 is indicative of how much the cost of allowing banks to go bankrupt outweighs the cost of subsidization in such severe circumstances. The government can also help the banks in which it has a major stake through preferential treatment, such as preferential loans when the government is creditor (Tian and Estrin, 2008). This preferential treatment could also include explicit bias when the government is the regulator, as it is the case in Indonesia.

We, therefore, expect loan announcement returns of state-owned banks to be less affected by the threat of expropriation than those of family-owned banks if the "helping hand" effect could potentially mitigate the "grabbing hand" effect in state-owned banks. We cannot directly test whether investors of state-owned banks anticipate that the "helping hand" effect could mitigate the "grabbing hand" effect as we cannot separately measure these two effects. However, as family-owned banks are also prone to expropriate minority shareholders (Claessens et al., 2002; Villalonga and Amit, 2006; Maury, 2006), our results will support this conjecture if we find that loan announcement returns are more affected by the threat of expropriation (gauged by the importance of related lending) in the case of family-owned banks compared to state-owned banks.

H1 (“helping hand effect” for SOBs): Loan announcement returns of state-owned banks are less affected by the threat of expropriation than those of family-owned banks.

To gain further insights into the market reaction to the loan announcements of state- and family-owned banks, we also need to consider if the loan is extended to a state-owned firm or a private firm. To avoid their possible failure, the state may provide preferential treatments to SOEs and subsidize them if they encounter financial difficulties (Faccio et al., 2006). Shareholders of state-owned banks could, therefore, benefit from a twin "helping hand" effect when the borrower is a SOE. We hence expect that the market reaction to loan announcements of state-owned banks depends on the type of borrowing firms. Shareholders might less negatively react to loan announcements of SOBs when the borrowing firm is a SOE than when the borrower is a private firm if they expect a twin "helping hand". It is also possible that the market anticipates that family-owned banks might also benefit from a "helping hand" effect when borrowers are SOEs.

H2a ("Twin helping hand" effect for SOBs lending to SOEs): When the borrower is a SOE and the lender a state-owned bank, loan announcement returns are less affected by the threat of expropriation than when the borrower of the SOB is a private firm. 
H2b ("Helping hand" effect for family-owned banks lending to SOEs): When the borrower is a SOE and the lender a family-owned bank, loan announcement returns are less affected by the threat of expropriation than when the borrower of the family-owned bank is a private firm.

The literature analyzing the reaction of bank stock prices to loan announcements is very scarce and does not specifically examine market reactions of state-owned banks. Working on a sample of 88 bank loan announcements in Japan, Kang and Liu (2008) find a negative impact of loan announcements on the stock returns of lending banks, while they observe a positive impact on the valuation of borrowing firms. They conclude that such findings are consistent with the hypothesis that banks make suboptimal lending decisions that lead to wealth transfers to borrowers. Bailey et al. (2011), who find no significant response for the stock prices of Chinese banks, fail to confirm these results. However, their investigation is limited to 24 loan announcements made by Chinese banks listed on the stock market.

Our paper is more closely related to Claessens et al. (1998), Bai et al. (2004) and Cheung et al. (2009) that examine whether non-financial firms benefit from the presence of government shareholding. These three papers provide opposite results, with Bai et al. (2004) showing that government ownership has a negative impact on market valuation, while Claessens et al. (1998) find no significant impact and Cheung et al. (2009) find a positive impact but only for central government ownership. We contribute to this literature by focusing on government ownership of banks, with potentially a stronger expected "helping hand" effect as government bailouts are much more common for banks than for non-financial firms. We furthermore investigate whether the type of the borrowing firm makes shareholders of state-owned banks differently react to loan announcements.

\section{Data and variable definitions}

\subsection{Presentation of the sample}

Since 2004, the Indonesian market authority obliges borrowing firms to report information on each loan contract no later than two working days after the transaction is undertaken to the Indonesian Financial Services Authorities (OJK) and in Indonesian newspapers. However, the information provided around the announcement date is often limited to the name of the lending bank and the loan size. More detailed information (contract date, the interest rate, and the maturity) are only provided in the annual report of borrowing firms. We, therefore, collected our data on bank loan announcements from the annual reports of borrowing firms and not from 
announcements to the Stock Exchange. ${ }^{3}$ We furthermore collect data on related party transactions from banks annual reports. We have reliable information since 2009 as the law requires listed Indonesian firms to publicly report any related party transaction (RPT). We also use the annual reports of banks to assemble data on their ownership structure, in addition to the information provided by BvD BankScope and Bloomberg. As discussed above, we only collect data on the ownership structure of banks until 2014. A regulation became effective in 2014 intending to reduce over the five following years the potential negative effects of ownership domination for the banking industry. The law was initially enacted in 2012 by the Central Bank (Central Bank of Indonesia regulation Nomor 14/8/PBI/2012), with maximum ownership limited to $40 \%, 30 \%$ and $20 \%$ for financial institution, non-financial institution, and individual/family, respectively. This limit takes into account if different shareholders are connected by stakes, family relationships or act in a concert relationship, and this is the total combined ownership of the whole connected parties that cannot exceed the maximum threshold. The adjustments in the ownership stakes start in 2014 and had to be made by the end of 2018 . However, this law does not apply to the central government of Indonesia and restructuration agencies. Based on these policies, we limit our analysis to the period $2009-2014,{ }^{4}$ by collecting market data over the period 2010-2014 as we use the lagged value of related party transactions in our empirical analysis.

Out of the 521 firms publicly listed on the Indonesian Stock Exchange (IDX) over the 20102014 period, 153 firms have taken out loans from banks and disclosed detailed information on the loan contracts. We obtain information on 421 loan contracts, involving 27 listed banks (among the 35 banks that are listed on the IDX over the period). Among these 27 banks, 12 are identified as state-owned, 12 are family-owned and 3 are institutionally-owned (the largest shareholder is an institutional investor), and they account for 211, 131 and 23 loan announcements, respectively. Because of the very small number of observations on institutionally-owned banks we drop them from our sample especially because our framework requires identifying the type of borrowers they lend to. We furthermore examine if other events may affect banks' stock prices around the loan announcements (e.g. dividend payments, change in managerial key position, etc.) in banks' annual reports and website corporate announcements;

\footnotetext{
${ }^{3}$ We did not use Thomson Reuters LPC DealScan to collect data on loan announcements for three reasons. First, only a small number of Indonesian banks ( 2 over our period of analysis) are involved in the market of syndicated loans. Second, this commercial database does not provide data on related party transactions; such data are only available in countries where it is mandatory to report them in annual reports, such as Indonesia. Third, syndicated loans involve several lenders for a given borrower.

${ }^{4}$ We keep the year 2014 in our analysis to gain in degrees of freedom because we observe that we do not have significant changes between 2013 and 2014 in the ownership structure of our sample of banks.
} 
we drop 23 loans announcement for which other events were identified. Because all the relevant data (financial statements, ownership structure, and related party transactions) on borrowing firms and lending banks are not available in either annual financial reports or Bloomberg and Bankscope, we end up with a final sample of 342 loans involving 136 borrowers and 24 lending banks. We verify that these 24 banks are actively traded on the market. Table 1 presents the distribution of loans, borrowing firms, and lending banks by year over the 2010-2014 period.

[Insert Table 1]

\subsection{Ownership structure of lending banks and borrowing firms}

Banks in Indonesia are generally controlled by one large shareholder until 2014. This could be due to the reforms imposed by the government over the 2000s. In 2005, the government provided incentives for consolidation by raising the minimum capital requirement to IDR 100 billion (PBI No 7/15/2005). In 2006, the Indonesian government further attempted to promote competition by preventing shareholders from having controlling stakes in multiple banks (PBI No. 8/16/PBI/2006), forcing them to divest or consolidate through mergers and acquisitions.

We follow the existing literature (e.g. La Porta et al., 1999, 2002; Caprio et al., 2007; Lepetit et al., 2015) by using the control threshold of $10 \%$ to build the control chain of banks for each year and identify all owners that have a controlling stake. We find that all banks have at least one controlling owner, with the largest and the second largest owner holding on average around $55 \%$ and $7 \%$ of the shares, respectively, leaving minority shareholders with on average a $34 \%$ stake.

We find that the largest owner is a government for 12 banks, with on average a controlling stake of around $63 \%$, while minority shareholders hold on average $31 \%$ of the shares (see Table 2). We have 8 banks controlled directly or indirectly by the government of Indonesia, and 4 banks controlled by a foreign government (Singapore, Malaysia, and Qatar). The 8 Indonesian state-owned banks account for a substantial market share with around $42 \%$ of the total assets of the banking system over the 2010-2014 period (for a total of 116 banks). We also have 12 family-owned banks, with families holding on average $42.6 \%$ of the shares (see Table 2). We find that the ownership structure of these state- and family-owned banks is stable over the sample period, the largest controlling owner remaining the same with however time-varying shareholdings. The number of loan announcements for state-owned and family-owned banks is 211 and 131, respectively (see Table 2). We can see that the size of the loan is on average larger for state-owned banks than for family-owned banks (see Table 2). We create the dummy 
variable DLenderGvtOwned, taking the value of one for loan contracts when the lender is government-owned, and zero otherwise.

For the borrowing firms, we identify if they are state- or privately-owned using the information provided by the company website and annual reports, the IDX, and the Ministry of SOEs. We have in our sample 10 borrowers that are SOEs among the 20 SOEs that are listed on the IDX, with the government holding more than $50 \%$ of the shares. These 10 borrowers account for 45 loan announcements. We, therefore, have 126 borrowers that are privately owned, accounting for 297 loan announcements. We create the dummy variable DBorrowerGvtOwned that takes the value of one for loan contracts when the borrower is government-owned.

[Insert Table 2]

\subsection{Related loans as a proxy for the likelihood of expropriation}

We try to identify which loans can be classified as related at the announcement date. In Indonesia, the regulator considers loans as related if: (i) borrowers and lenders are owned by the same controlling shareholder(s); or (ii) borrowing firms are controlled by a key person in lenders' management (executive manager, director, etc.). Since 2009, the regulation requires listed Indonesian firms to publicly announce any related party transaction (RPT) a maximum of two working days after the transaction takes place, except for related party transactions having a value lower than $0.5 \%$ of the firm's paid capital (BAPEPAM Kep-412/BL/2009). Such rules might create incentives for firms to arrange RPT and split them into smaller ones; this implies that investors on the market might not be aware of all RPTs when they take place, but instead only have information, ex-post, on the total amount of RPTs that are disclosed in annual reports since 2009 (Indonesian accounting standard regulation PSAK No. 7/2009). Moreover, if related parties and controlling owners are in the same group with consolidated annual reports, the status of the transactions (RPT or non-RPT) does not need to be publicly announced to the IDX although they need to be reported to the Indonesian Financial Services Authorities (OJK) and in borrowing firms' annual reports. Listed banks are furthermore subject to the rules imposed by the Central Bank of Indonesia; since 2005, loans extended to related parties cannot exceed 10\% of the banks' equity (Peraturan Bank Indonesia No. 7/3/PBI/2005).

In this context, market participants will not be able to identify all loans that are related using public information available at the announcement date. We cannot, therefore, conduct our event study analysis using the information on loans classified as related at the announcement date, as 
a large number of loans will be classified as non-related while they are related. ${ }^{5}$ The only reliable information is the information on related loans provided in the annual report. We, therefore, use the information published in banks' annual reports on loans to related parties as a proxy for the likelihood of expropriation, as common in the existing literature (e.g. Bailey et al., 2011, Djankov et al., 2008; Huang et al., 2012). Related party transactions can be used by large shareholders as a vehicle to transfer resources from the company to its related parties (La Porta et al. 2003; Gordon et al., 2004; Jiang et al. 2010). Such expropriation behavior with the pursuit of non-profit maximizing objectives could affect minority shareholders through a reduction in firm value. Alternatively, related party transactions could also take the form of efficient arrangements that are of benefit to all shareholders when there is incomplete information (Ryngaert and Thomas, 2012). This can be the case if the availability of more information on related parties reduces the uncertainty on the risk characteristics of projects (Rajan, 1992). However, the existing empirical literature finds that related party transactions are negatively related to firm value, supporting the expropriation hypothesis (Gordon et al., 2004; Cheung et al. 2009; Jiang et al. 2010; Kohlebeck and Mayhew, 2010; Ryngaert and Thomas, 2012).

We collect data on the total amount of related loans provided in banks annual reports for the years 2009 to 2014 and compute for each bank the ratio of related loans to total loans (RelatedLoans1) and the ratio of related loans to total assets (RelatedLoans2). Related loans represent on average around $3.8 \%$ of total loans, with a median value of $0.30 \%$ (see Table 3 ). On average, the proportion of related loans is higher for state-owned banks (5.67\%) compared to family-owned banks (0.9\%) (see Table 2).

\section{[Insert Table 3]}

\section{Abnormal returns surrounding loan announcements}

\subsection{Event study methodology}

We investigate the impact of loan announcements on stock prices of state-owned banks in comparison to family-owned banks over the period 2010-2014. The announcements of individual loan agreements can have a significant effect on the stock prices of the lending bank although loans to an individual firm generally represent a small portion of a bank's loan portfolio (Kang and Liu, 2008). They provide information to the market about the bank's lending policy and how the bank invests its funds to generate cash flows.

\footnotetext{
${ }^{5}$ Based on the information publicly available, we can only identify 54 loans that are related among the 342 loans announcements we have in our sample.
} 
We apply a standard event study methodology to compute CARs for all announcements. The date of the loan announcement is the date of the loan contract plus two working days as the loan transactions should be announced within a maximum of two working days. We obtain daily stock prices and market index data from Bloomberg. We compute ex-post abnormal returns, defined as the difference between actual stock returns and expected returns in the event window, as follows:

$$
A R_{i t}=R_{i t}-\left(\hat{\alpha}_{i}+\hat{\beta}_{i} R_{m t}\right)
$$

where $R_{i t}$ is the daily return of the ith lending bank at time $t$ and $R_{m t}$ is the daily market index return at time $t ; \hat{\alpha}_{i}$ and $\hat{\beta}_{i}$ are ordinary least squares (OLS) regression estimates from the market model. We compute the abnormal returns by estimating $\hat{\alpha}_{i}$ and $\hat{\beta}_{i}$ using 180 daily returns beginning with day $\mathrm{t}=-200$ and ending with $\mathrm{t}=-20$ relative to the announcement date $\mathrm{t}=0$.

We calculate the cumulative abnormal returns between any two dates $\mathrm{T}_{1}$ and $\mathrm{T}_{2}$ as

$$
\operatorname{CAR}_{i}\left(T_{1}, T_{2}\right)=\sum_{t=T 1}^{T 2} \mathrm{AR}_{i t}
$$

and we construct the cross-sectional average of CARs between dates $T_{1}$ and $T_{2}$ as

$$
\operatorname{ACAR}_{i}\left(T_{1}, T_{2}\right)=\frac{1}{N} \sum_{i=1}^{N} \operatorname{CAR}_{i}\left(T_{1}, T_{2}\right)
$$

We test the significance of average CARs using the standard cross-sectional t-statistic test that the average CARs over any given time interval are equal to zero. We also employ the Wilcoxon test (1945) that uses a median test of the null hypothesis to check if the mean return is not unduly influenced by outlier returns.

\subsection{Results}

Tables 4 reports the CARs for state-owned banks (Panel B) in comparison with familyowned banks (Panel C), that we further differentiate according to their relatively high or low levels of related loans. ${ }^{6}$ Panel A also reports the results for the whole sample. We consider different event windows spanning from 3 days before and 3 days after the loan announcement date. We use the sample median value of the ratio of related loans to total loans (RelatedLoans1) in $\mathrm{t}-1$ in the period preceding the announcement date to differentiate banks with relatively high and low likelihood of expropriation.

Panel A for the whole sample shows that there are significant negative CARs at the 1 or $5 \%$ confidence levels for banks. These negative CARs are driven by banks with relatively high

\footnotetext{
${ }^{6}$ We have also computed CARs for state- and family-owned banks depending on the level of their related loans (high or low) and also on the type of borrowers they lend to (SOEs vs. privately-owned). However, dividing each sub-group of banks into four subsamples leaves some cases with a very small number of observations (or even no observations).
} 
levels of related loans for two of the three-event windows we consider. We furthermore observe that the stock market reacts negatively to loan announcements of family-owned banks with higher levels of related loans for the event windows $[-3,+3]$ and $[-1,+1]$ (Panel C). CARs for family-owned banks with lower levels of related loans are consistently non-significant. Regarding state-owned banks, Panel B shows that CARs are non-significant for state-owned banks with a relatively high level of related party loans, for the three-event windows we consider and for both the $t$-statistic and the Wilcoxon tests. But for state-owned banks with relatively lower levels of related loans, the abnormal returns are significantly negative for the two event windows $[-2,+2]$ and $[-1,+1] .{ }^{7}$ Together with the finding of negative announcement returns for family-owned banks with relatively high levels of related loans, the absence of significant negative returns for state-owned banks with high levels of related loans is consistent with hypothesis 1 . These results support the argument that investors expect the "helping hand" effect to mitigate the "grabbing hand"effect.

\section{[Insert Table 4]}

\section{Determinants of loan announcement effect}

\subsection{Type of banks and levels of related loans}

We next conduct a cross-sectional regression analysis to determine how government ownership affects the market valuation of banks by considering the likelihood of expropriation as measured by the importance of related loans. We use a CAR event window of $[-2,+2]$ as the dependent variable ${ }^{8}$ and consider family-owned banks as a benchmark as follows:

$$
\begin{aligned}
\text { CAR }_{i}=\beta_{0}+ & \beta_{1} \text { RelatedLoans }_{i}+\beta_{2} \text { RelatedLoans }_{i} \times \text { DLenderGvtOwned }_{i} \\
& +\beta_{3} \text { DLenderGvtOwned }_{i}+\sum_{m} \theta_{m} \text { Control }_{i}+\varepsilon_{i}
\end{aligned}
$$

where RelatedLoans is either the ratio of related loans to total loans (RelatedLoans1) or the ratio of related loans to total assets (RelatedLoans2) in the period preceding the announcement date; DLenderGvtOwned takes the value of one when the lending bank is government-owned. To be in line with hypothesis 1 , we expect loan announcement returns of state-owned banks to be less affected by the threat of expropriation than those of family-owned banks.

\footnotetext{
${ }^{7}$ This unexpected result is driven by foreign state-owned banks. Indeed, in our sample, most of the state-owned banks with relatively low levels of related lending are foreign (see Section 6). Not surprisingly, state-owned banks are less likely to develop such links in a foreign country than at home.

${ }^{8} \mathrm{We}$ check the robustness of our results by considering other CAR event windows in Section 7.
} 
We include a set of control variables in Equation (4). All variables are defined in Table 3 with corresponding descriptive statistics. We first control for loan characteristics. We include the ratio of loan size to the total assets of the borrowing firm (LoanSize) and expect a negative sign if the market perceives loans as suboptimal with a wealth transfer to borrowers ( Kang and Liu, 2008). We also consider the maturity of loans in years (TenureYear); we expect a negative coefficient if loans with longer maturity are associated with higher probabilities of default. We control for the interest rate fixed by banks (InterestRate); a positive coefficient is expected if higher interest rates contribute to increase bank profits. We furthermore include a set of variables to control for borrowers' and banks' characteristics (taking lagged values): the ROA (BorrowerROA and LenderROA), the leverage ratio (BorrowerLeverage and LenderLeverage), and the logarithm of total assets (BorrowerSize and LenderSize). We furthermore compute an index to measure the degree of bank opacity (LenderOpacity), as banks with lower degrees of opacity should display lower CARs. We consider two components in our opacity index: trading volume as a proxy for information uncertainty and asymmetry (e.g., Leuz and Verrecchia 2000, Bailey et al. 2003) and bid-ask-spreads as a proxy for information asymmetry among investors (Leuz and Verrecchia 2000; Mohd 2005). The index ranges from one to ten, with the highest value representing the highest level of opacity (see Table 3 for more details). We analyze the correlation matrix of our variables and does not point to potential multicollinearity problems.

Equation (4) is estimated using the ordinary least squared estimator with standard errors clustered at the bank level. ${ }^{9}$ We also run regressions where we only include the variable RelatedLoans and the dummy variable DLenderGvtOwned without considering their interaction. The results are all provided in Table 5. When we consider the basic regression without the interplay between the level of related lending and the type of bank (state-owned versus family-owned), we find that announcement returns are not significantly related to either the extent of related lending or the type of the bank at the 1 or $5 \%$ confidence levels (see columns (1) and (3)).

However, the results in columns (2) and (4) in Table 5 show that, for family-owned banks (that we consider as a benchmark), announcement returns are negatively linked to the extent of related lending in banks' balance sheets ( $\beta_{1}$ negative and significant). Our results show a different market reaction when the bank is controlled by the government as opposed to a family as the coefficient $\beta_{2}$ is positive and significant. Wald tests show that announcement returns of state-owned banks are not significantly related to the importance of related lending $\left(\beta_{1}+\beta_{2}\right.$

\footnotetext{
${ }^{9}$ We find similar results when standard errors are clustered at the bank and borrower level.
} 
non-significant). Our findings are therefore consistent with hypothesis 1 . These results seem to indicate that even if a risk of expropriation exists when a state is the controlling owner of a bank, it is mitigated by the "helping hand" effect. Our empirical analysis provides, therefore, evidence that shareholders do not anticipate being affected by government shareholdings in banks, while they negatively value the presence of families as controlling shareholders.

[Insert Table 5]

\subsection{Impact of the borrowing firm's type}

We further examine whether market reactions to loan announcements of state-owned banks in comparison to family-owned banks also depend on the type of firms they lend to. ${ }^{10}$ To examine this potential impact channel, we augment Equation (4) with terms interacting the ratio of related loans (RelatedLoans), the dummy variable for government-owned banks (DLenderGvtOwned), and the dummy variable for government-owned borrowing firms (DBorrowerGvtOwned); the estimation results are given in Table 6, with Table 7 providing the associated Wald tests.

Our results in Tables 6 and 7 show that announcement returns are negatively related to the extent of related lending when the controlling shareholder is a family, but only when loans are extended to privately-owned firms. In contrast, our results show that announcement returns are not significantly affected when loans are extended by family-owned banks to state-owned firms. Our results furthermore show that announcement returns are positively and significantly related to the extent of related lending when the controlling shareholder is a government, but only when loans are extended to state-owned firms. We find no significant relationship when loans are extended to privately-owned firms.

These results taken altogether are consistent with hypothesis 2. Even if a risk of expropriation exists, the market positively values the government ownership of banks when loans are extended to state-owned firms as compared to loans extended to privately-owned firms, and does not negatively value family-ownership when the borrower is state-owned. These findings support the arguments that when state-owned banks extend loans to SOEs, the twin "helping hand" effect outweighs the "grabbing hand" effect. For family-owned banks, our results seem to indicate that when borrowers are SOEs, the market anticipates such banks might also benefit from a "helping hand" effect that could mitigate the risk of expropriation.

$$
\text { [Insert Tables } 6 \text { and 7] }
$$

\footnotetext{
${ }^{10}$ As we only have listed firms in our sample of borrowers, they are all profit maximizing.
} 


\section{Extensions to analysis}

We now examine several additional factors that could also have an impact on market reactions to loan announcements of state-owned banks in comparison to family-owned banks.

\section{Type of government}

We first examine whether the valuation effect of loan announcements is different when stateowned banks are controlled either by the government of Indonesia or by a foreign government. The market might anticipate that foreign governments are less likely to provide preferential treatment or to bail-out banks when they are shareholders of banks located in a foreign country, while they might expropriate shareholders' wealth for their benefit. We have 8 state-owned banks controlled by the government of Indonesia and 4 by a foreign government, accounting for 168 and 43 loan announcements, respectively. ${ }^{11}$ Table 8 reports the CARs for Indonesian state-owned banks (Panel A) and foreign state-owned banks (Panel B) with either high or low levels of related loans. We note that all the foreign state-owned banks have a level of related loans lower than the median sample. We observe from Panel A that CARs are consistently nonsignificant for Indonesian state-owned banks with relatively high and low levels of related loans, for the threeevent windows we consider. In contrast, we find that announcement returns of foreign state-owned banks loan agreements are significantly negative. These results indicate that the negative valuation effect of loan announcement we find for state-owned banks with low levels of related loans in Table 4 is driven by foreign state-owned banks.

We next compute the two dummy variables DLenderIndGvtOwned and DLenderForGvtOwned taking the value of one when the largest shareholder is the government of Indonesia or a foreign government, respectively. We test whether the type of government affects our results by augmenting Equation (4) with terms interacting the ratio of related loans and the two dummy variables for Indonesian and foreign state-owned banks. ${ }^{12}$ The results provided in Table 9 show that despite the positive and significant coefficient associated with DLenderIndGvtOwned and the non-significant coefficient of DLenderForGvtOwned, the Wald tests show that announcement returns of both Indonesian and foreign state-owned banks are not significantly linked to the importance of related lending. These findings confirm that shareholders of state-owned banks do not anticipate being affected by government shareholdings in banks, and this result holds irrespective of the type of government.

\footnotetext{
${ }^{11}$ Two banks are controlled by the government of Malaysia, one by the government of Singapore and one by the government of Qatar.

${ }^{12}$ The number of loan announcements for foreign state-owned banks does not allow us to run the regressions when we consider the type of borrowers as in Tables 6 and 7.
} 
[Insert Tables 8 and 9]

\section{Co-insurance effect}

Concerning privately-owned borrowing firms, an important feature we need to consider is that borrowers belonging to a pyramidal business group could present lower default risk. The business groups enable member firms to share risk by reallocating resources from one affiliate to another firm (Friedman et al., 2003; Khanna and Yafeh, 2005, 2007; Gopalan et al., 2007). There is some empirical evidence of co-insurance within pyramidal business groups. Chang and Hong (2000) find that pyramidal business groups in Korea use internal business transactions for cross-subsidization purposes. Gopalan et al. (2007) further find that groupaffiliated firms in India are less likely to go bankrupt than stand-alone firms. Shareholders of state-owned banks could therefore benefit from the cumulative effect of the "helping hand" and co-insurance effects when borrowers belong to a pyramidal business group.

Among the privately-owned borrowers, we identify 115 borrowers belonging to a pyramidal business group and 11 with a horizontal ownership structure, accounting for 278 and 19 loan announcements, respectively. We rerun our regressions by differentiating if privately-owned borrowing firms are affiliated or not to a pyramidal business group; we compute for that the dummy variable DBorrowerInGroup taking the value of one when the borrower is privatelyowned and belongs to a pyramidal business group, and zero otherwise. The estimation results are reported in Table 10 and associated Wald tests in Table 11.

Wald tests show that announcement returns of state-owned banks are significantly related to the importance of related lending when the borrower is government-owned, while we find no significant relationship when loans are extended to privately-owned firms and irrespective of whether or not they are affiliated to a business group. For family-owned banks, the potential co-insurance effect when loans are extended to borrowers affiliated to a pyramidal business group does not offset the risk of expropriation, but the co-insurance effect contributes to attenuate the negative market valuation associated with family shareholdings.

[Insert Tables 10 and 11]

\section{Proportion of independent directors}

The appointment of independent directors, who are independent from the influence of the management and controlling shareholders, are considered as an essential tool to mitigate the risk of resource diversion and transfer of firm value away from minority shareholders (Dahya and McConnell, 2005; Young et al., 2008). We, therefore, check if the market reaction to bank 
loan announcements when taking the likelihood of expropriation into account does not depend on the proportion of independent directors on the board.

The Company Law in Indonesia adopts a two-tier board structure, with a board of directors (BOD) and a board of commissioners (BOC). The BOD consists of only firms' executive and has managerial or day-to-day operational responsibilities, while the BOC is in charge of ensuring the implementation of the corporate strategy, supervision of management policies, and advising the BOD. The role of BOC is therefore comparable to that of the board of directors in a one-tier board structure. Under the Central Bank of Indonesia Regulation No. 8/14/PBI/2006 on the implementation of corporate governance for banks, banks must have a minimum of 50\% of commissioners who are independent since 2006 . We have in our sample around $25 \%$ of banks having just the minimum legal of $50 \%$ of independent commissioners. We compute the dummy variable DHighIndepDirectors that takes the value of one when the proportion of independent commissioners is strictly higher than 50\%. We augment Equation (4) with terms interacting the ratio of related loans, the dummy variable for state-owned banks, and the dummy variable for banks with a proportion of independent commissioners higher than the minimum imposed by the regulator. Results provided in Tables 12 and 13 show that the relationships between abnormal returns and the extent of related loans in state- and family-owned banks do not depend on the proportion of independent commissioners on the board.

[Insert Tables 12 and 13]

\section{Robustness checks}

To check the robustness of our results, we conduct several tests.

\section{Alternative event windows and tests for abnormal returns}

To determine whether our results are affected by the event-windows we consider, we compute CARs in $[0,+1],[0,+2]$, and $[-1,+2]$ windows. The results, provided in Table A1 in the Appendix, show that our main results remain unchanged. Furthermore, as the T-test is not immune to how abnormal returns are distributed across the event windows, we use alternatively both Pattel (1976) and Boehmer et al. (1991) tests that consider abnormal returns distribution, event-induced volatility and serial correlation to tackle this issue. Again, our main results remain unchanged (see Table A1).

We also rerun regressions of Tables 5 and 6 on the three alternative event windows $[0,+1]$, $[0,+2]$, and $[-1,+2]$ and find results similar to those of the $[-2,+2]$ event-window. To save space, 
we only report in Appendix the results when we consider the type of borrowers and when the dependent variable is the ratio of related loans to total loans (see Tables A2 and A3). Our results when the lender is a state-owned bank are unchanged. When banks are controlled by a family, we find that announcement returns are negatively related to the extent of related lending, not only when loans are extended to privately-owned firms as we previously found, but also to SOEs for the two event windows $[-1,+2]$ and $[0,+1]$. Our results indicating that the "helping hand" effect is also present in family-owned banks when they lend to SOEs is therefore not robust across all the event windows.

\section{Role of the size of loans}

The market reaction to loan announcements might depend on the size of the loan (Kang and Liu, 2008), especially in our study where we are taking into account the likelihood of expropriation. We therefore examine whether our results are not driven by a stronger market reaction for large loans. We create the dummy variable DLargeLoans which takes the value of one if the loan size is above the median sample. In our sample, the average amount of stateowned banks loans is relatively high around 412.31 Billion rupiahs compared to family-owned banks (177.20 Billion rupiahs) (see Table 2). Loans from state-owned banks account therefore for $62.20 \%$ of the loans that we classify as large.

We test whether the size of the loan affects our results by augmenting Equation (4) with terms interacting the ratio of related loans, the dummy variable for state-owned banks, and the dummy variable DLargeLoans. ${ }^{13}$ The results provided in Tables A4 and A5 show that the relationships between abnormal returns and the extent of related loans in state-owned and family-owned banks do not depend on the size of the loan.

\section{Several lenders to the same firm}

We check if some borrowers benefit from several loans provided by both state-owned banks and family-owned banks. We have 131 and 77 loan announcements for which the borrowers get loans only from state-owned or family-owned banks, respectively, with the remainder borrowings from both state-owned and family-owned banks over time. We verify whether the market reaction to loan announcements for state-owned banks depends on the other loan contracts the borrowers have with family-owned banks. We create for that a dummy variable DLenderGvtOwnedOnly taking the value of one for a borrower with only state-owned banks as

\footnotetext{
${ }^{13} \mathrm{We}$ are not able to run regressions when considering the type borrowers banks lends to as it would require including quadruple interaction terms.
} 
lenders, and the dummy variable DBothLenders that takes the value of one for a borrower whose lenders are both state-owned banks and family-owned banks. The results provided in Table A6 show that the results we find hold independently of whether state-owned banks are the sole lenders of borrowers over time.

\section{Sub-sample analysis}

Cheung et al. (2009), who analyze abnormal stock returns at the announcement of related party transactions for Chinese SOEs, find results consistent with the "helping hand" hypothesis when the controlling shareholder is the central government, while their results support the "grabbing hand" hypothesis when SOEs are controlled by local governments. They justify these results by arguing that local governments might have more opportunities to expropriate as they have lower visibility to the press and judicial authorities compared to the central government. In our sample, we only have 2 state-owned banks controlled by local Indonesian governments, accounting for 6 observations. We cannot therefore examine whether the market reaction to state-owned banks' loan announcements depends on the type of government, local or central. However, we check the robustness of our results by excluding the 6 loan announcements made by state-owned banks controlled by local governments, and our results remain unchanged (see Tables A7 to A9).

\section{Conclusion}

This study examines whether government ownership affects the market valuation of banks when they extend their activities. We use a unique hand-collected dataset for Indonesia to analyze the impact of loan announcements on the bank stock returns of state-owned banks when expropriation is at stake, by taking family-owned banks as a benchmark. While minority shareholders of state-owned banks might expect a lower return from new loans because of expropriation ("grabbing hand" effect), they might also perceive them as less risky because of the higher probability of government bailout ("helping hand" effect). We also investigate whether the type of the borrowing firm (state-owned firm vs. private firm) makes shareholders of state-owned banks react more or less strongly to loan announcements.

Our findings show that, as expected, for family-owned banks there is a significant negative relationship between announcement returns and the extent of expropriation while there is no such link for state-owned banks. Hence, for similar levels of expropriation in both types of banks, only the stock prices of family-owned banks suffer from loan announcements. Taken 
altogether, these findings are consistent with the conjecture that even if a "grabbing hand" effect is also prevalent in state-owned banks, such a negative impact for shareholders seems to be offset by the "helping hand" effect. These results hold for banks controlled by either the government of Indonesia or a foreign government, and irrespective of whether state-owned banks are the sole lenders of borrowers over time, the size of the loan and the proportion of independent directors on the board.

Our results further show that the "helping hand" effect at state-owned banks is stronger when loans are granted to state-owned firms rather than to private firms, and irrespective of whether or not they are affiliated to a business group. At family-owned banks, stock prices systematically decline but suffer less when borrowing firms are affiliated to a pyramidal business group. Taken altogether, these results provide evidence that when state-owned banks extend loans to SOEs, the expected twin "helping hand" effect outweighs the "grabbing hand" effect. For family-owned firms, the potential co-insurance effect when loans are extended to borrowers affiliated to a pyramidal business group does not seem to offset the negative impact due to expropriation.

Our empirical analysis, therefore, provides evidence that shareholders of state-owned banks do not anticipate being affected when expropriation is at stake, while in contrast, those of family-owned banks expect to be negatively affected. Our findings have implications for governments, financial market authorities and listed companies. Our findings support the view that shareholders rationally anticipate being exproriated when investing in state-owned banks in countries with weak shareholder protection, but are willing to accept this higher risk in exchange for greater stability. The findings also indicate that shareholders believe that governments will bail out state-owned firms in case of distress. Our results suggest that if governments maintain controlling positions in many banks in both developing and developed countries, shareholders will not systematically "punish" them by selling stocks when they make bad or riskier investments because they feel safe. Such behavior can lead to severe resource misallocation. However, the implementation of default resolution mechanisms to impose the losses on majority as well as minority shareholders in both government and private banks could change the way investors value bank government ownership. 


\section{References}

Bai, Chong-En., Li, David D., Tao, Zhigang., Wang, Yijiang, 2000. A multitask theory of state enterprise reform. Journal of Comparative Economics 28, 716-738.

Bai, Chong-En., Liu, Qiao., Lu, Joe., Song, Frank M., Zhang, Junxi, 2004. Corporate governance and market valuation in China. Journal of Comparative Economics 32, 599616.

Bailey, Warren, Huang, Wei, Yang, Zhisu, 2011. Bank loans with chinese characteristics: some evidence on inside debt in a state- controlled banking system. Journal of Financial and Quantitative Analysist 46, 1795-1830.

Bailey, Warren, Li, Haitao, Mao, Connie X., Zhong, Rui, 2003. Regulation fair disclosure and earnings information: market, analyst, and corporate responses. Journal of Finance 58, 2487-2514.

Berger, Allen N., Clarke, George R. G., Cull, Robert, Klapper, Leora, Udell, Gregory F, 2005. Corporate governance and bank performance: a joint analysis of the static, selection, and dynamic effects of domestic, foreign, and state ownership. Journal of Banking and Finance 29, 2179-2221.

Berger, Allen N., Hasan, Iftekhar., Zhou, Mingming, 2009. Bank ownership and efficiency in China: what will happen in the world's largest nation?. Journal of Banking and Finance 33, 113-130.

Boehmer, Ekkehart, Masumeci, Jim, and Poulsen, Annete B., 1991. Event study methodology under conditions of event-induced variance. Journal of Financial Economics 30, 253-272.

Bonin, John P., Hasan, Iftekhar., Wachtel, Paul, 2005. Bank performance, efficiency and ownership in transition countries. Journal of Banking \& Finance 29, 31-53.

Caprio, Gerard, Laeven, Luc, and Levine, Ross, 2007. Governance and bank valuation. Journal of Financial Intermediation16, 584-617.

Chang, Sea J., Hong, Jaebum, 2000. Economic performance of group-affiliated companies in Korea, Intragroup resource sharing and internal business transactions. Academy of Management Journal 43, 429-448.

Cheung, Yan-Leung, Rau, P. Raghavendra Stouraitis, Aris. 2009. Helping hand or grabbing hand? Central vs. local government shareholders in Chinese listed firms. Review of finance $14,669-694$.

Claessens, Stijn, Demirguc-Kunt, Asli, Huizinga, Harry, 1998. How does foreign entry affect the domestic banking market?. Policy Research Working Paper Series, The World Bank.

Claessens, Stijn, Djankov, Simeon, Fan, Josph P.H., Lang, Larry H.P., 2002. Disentangling the 
incentive and entrenchment effects of large shareholdings. Journal of Finance 57, 27412771.

Dahya, Jay, McConnell, John J., 2005. Outside directors and corporate board decisions. Journal of Corporate Finance 11, 37-60.

Dinç, I.Sedar, 2005. Politicians and banks: political influences on government-owned banks in emerging markets. Journal of Financial Economics 77, 453-479.

Djankov, Simeon, La Porta, Rafael, Lopez-de-Silanes, Florencio, Shleifer, Andrei, 2008. The law and economics of self-dealing. Journal of Financial Economics 88, 430-465.

Faccio, Mara, Masulis, Ronald W., Mcconnell, John J., 2006. Political connections and corporate bailouts. Journal of Finance 61, 2597-2635.

Friedman, Eric, Johnson, Simon, Mitton, Todd, 2003. Propping and tunneling. Journal of Comparatvie Economics 31, 732-750.

Frye, Timothy, Shleifer, Andrei, 1996. The invisible hand and the weightless economy. American Economic Review 87, 354-358.

Gopalan, Radhakrishnan, Nanda, Vikram, Seru, Amit .2007. Affiliated firms and financial support: evidence from Indian business groups. Journal of Financial Economics 86, 759795.

Gordon, Elizabeth A., Henry, Elaine, Palia, Darius, 2004. Related Party Transactions: Associations with Corporate Governance and Firm Value. SSRN Electronic Journal. Available at https://doi.org/10.2139/ssrn.558983.

Huang, Weihua, Schwienbacher, Armin, Zhao, Shan, 2012. When bank loans are bad news: evidence from market reactions to loan announcements under the risk of expropriation. Journal of International Financial Markets, Institutions and Money 22, 233-252.

Jiang, Guohua, Lee, Charles M.C., Yue, Heng, 2010. Tunneling through intercorporate loans: the China experience. Journal of Financial Economics 98, 1-20.

Khanna, Tarun, Yafeh, Yishay, 2007. Business groups in emerging markets: paragons or parasites?. Journal of Economic Literature 45, 331-372.

Khanna, Tarun, Yafeh, Yishay, 2005. Business groups and risk sharing around the world. Journal of Business 78, 301-340.

Kang, Jun-Koo, Liu, Wei-Lin, 2008. Bank incentives and suboptimal lending decisions: evidence from the valuation effect of bank loan announcements in Japan. Journal of Banking and Finance 32, 915-929.

Khwaja, A.I. and Mian, A. (2005), "Do Lenders Favor Politically Connected”, Quarterly Journal of Economics, Vol. 120 No. 4, pp. 1371-1411. 
Kohlbeck, Mark, Mayhew, Brian W., 2010. Valuation of firms that disclose related party transactions. Journal of Accounting and Public Policy 29, 115-137.

La Porta, Rafael, Lopez-de-Silanes, Florencio, Zamarripa, Guillermo, 2003. Related Lending. Quarterly Journal of Economics 118, 231-268.

La Porta, Rafael, Lopez-De-Silanes, Florencio, Shleifer, Andrei, 2002. Government ownership of banks. Journal of Finance 57, 265-301.

La Porta, R., Lopez-de-silanes, F. and Shleifer, A. (Nat. B. of E.R. (1999), "Corporate Ownership around the World Corporate Ownership Around the World", The Journal of Finance, Vol. 54 No. 2, pp. 471-517.

Lepetit, Laetitia., Saghi-Zedek, Nadia, Tarazi, Amine, 2015. Excess control rights, bank capital structure adjustments, and lending. Journal of Financial Economics 115, 574-591.

Leuz, Christian, Verrecchia, Robert E., 2000. The economic consequences of increased disclosure. Journal of Accounting Research 38, 91-125.

Lin, Justin Y., Li, Zhiyun, 2008. Policy burden, privatization and soft budget constraint. Journal of Comparative Economics 36, 90-102.

Maury, Benjamin, 2006. Family ownership and firm performance: empirical evidence from Western European corporations. Journal of Corporate Finance 12, 321-341.

Megginson, William L., 2005. The economics of bank privatization. Journal of Banking and Finance 29, 1931-1980.

Mohd, Emad, 2005. Accounting for software development costs and information asymmetry. The Accounting Review 80, 1211-1231.

Patell, James M., 1976. Corporate forecasts of earnings per share and stock price behavior: empirical tests. Journal of Accounting Research 14, 246-276.

Peraturan Bank Indonesia, 2005. Regulation Number: 7/3/PBI/2005. Available at https://www.bi.go.id/id/peraturan/perbankan/Pages/pbi\%207305.aspx. BI, Jakarta.

Peraturan Bank Indonesia, 2005. Regulation Number: 7/15/PBI/2005. Available at https://www.bi.go.id/id/peraturan/perbankan/Pages/pbi\%2071505.aspx. BI, Jakarta

Peraturan Bank Indonesia, 2006. Regulation Number: 8/14/PBI/2006 Available at https://www.bi.go.id/id/peraturan/perbankan/Pages/pbi_81406.aspx. BI, Jakarta

Peraturan Bank Indonesia, 2007. Regulation Number: 8/16/PBI/2006 Available at https://www.ojk.go.id/en/kanal/perbankan/regulasi/peraturan-bank indonesia/Pages/bank-indonesia-regulation-number-8-16-pbi-2006.aspx OJK, Jakarta

Peraturan Bapepam Indonesia, 2009. Regulation Number: Kep-412/BL/2009 Available at https://www.ojk.go.id/id/kanal/pasar-modal/regulasi/klasifikasi-bapepam/emiten-dan- 
perusahaan-publik/Pages/benturan-kepentingan.aspx OJK, Jakarta

Peraturan Penyajian Standar Akuntansi Keuangan, PSAK No. 7 revision 2009. Available at http://www.iaiglobal.or.id/v03/standar-akuntansi-keuangan/pernyataan-sak-12-psak-7pengungkapan-pihakpihak-berelasi IAI, Jakarta

Rajan, Raghuram G. 1992. Insiders and outsiders : the choice between informed and arm ' slength debt. The Journal of Finance 47, 1367-1400.

Ryngaert, Michael, Thomas, Shawn, 2012. Not all related party transactions (RPTs) are the same: ex ante versus ex post RPTs. Journal of Accounting Research 50, 845-882.

Sapienza, Paola, 2004. The effects of government ownership on bank lending. Journal of Financial Economics 72, 357-384.

Shaban, Mohammed, James, Gregory A., 2018. The effects of ownership change on bank performance and risk exposure: evidence from Indonesia. Journal of Banking \& Finance $88,483-497$.

Shleifer, Andrei, Vishny, Robert W., 1998. The Grabbing Hand: Government Pathologies and Their Cures. Harvard Univ. Press, Cambridge, MA.

Shleifer, Andrei, Vishny, Robert W. 1994. Politicians and firms. Quarterly Journal of Economics 109, 995-1025.

Tian, Lihui, Estrin, Saul, 2008. Retained state shareholding in Chinese PLCs: does government ownership always reduce corporate value? . Journal of Comparative Economics 36, 74-89.

Villalonga, Belen, Amit, Raphael, 2006. How do family ownership, control and management affect firm value?. Journal of Financial Economics 80, 385-417.

Wilcoxon, Frank, 1945. Individual comparisons by ranking methods. Biometrics bulletin 1, 80-83.

Young, Michael N., Peng, Mike W., Bruton, Garry D., and Jiang, Yi, 2008. Corporate governance in emerging economies: a review of the principal-principal perspective. Journal of Management Studies 45, 196-220. 
Table 1. Distribution of the sample by year

\begin{tabular}{lccc}
\hline Years & $\begin{array}{c}\text { Number of loan } \\
\text { announcements }\end{array}$ & $\begin{array}{c}\text { Number } \\
\text { of borrowing firms }\end{array}$ & $\begin{array}{c}\text { Number } \\
\text { of lending banks }\end{array}$ \\
\hline 2010 & 92 & 50 & 16 \\
2011 & 66 & 49 & 13 \\
2012 & 64 & 49 & 17 \\
2013 & 63 & 33 & 20 \\
2014 & 57 & 47 & 22 \\
Total over the period & $\mathbf{3 4 2}$ & $\mathbf{1 3 6}$ & $\mathbf{2 4}$ \\
\hline
\end{tabular}

This table reports the distribution of loans announcements, number of borrowers and lenders by year over the period 2010 to 2014 .

Table 2. Descriptive statistics by category of banks

\begin{tabular}{|c|c|c|}
\hline & State-owned banks & Family-owned banks \\
\hline Number of banks & 12 & 12 \\
\hline $\begin{array}{l}\text { Number of loan } \\
\text { announcements }\end{array}$ & 211 & 131 \\
\hline \multicolumn{3}{|l|}{$\begin{array}{l}\% \text { of shares of the largest } \\
\text { shareholder }\end{array}$} \\
\hline Mean & 62.94 & 42.6 \\
\hline Min & 25.66 & 15.42 \\
\hline Max & 96.92 & 69.9 \\
\hline Std. & 14.60 & 11.84 \\
\hline \multicolumn{3}{|l|}{$\begin{array}{l}\% \text { of shares held by } \\
\text { minority shareholders }\end{array}$} \\
\hline Mean & 31.13 & 38.70 \\
\hline Min & 2.62 & 12.16 \\
\hline Max & 43.25 & 54.74 \\
\hline Std. & 14.25 & 13.31 \\
\hline \multicolumn{3}{|l|}{$\begin{array}{l}\text { Loan announcement size } \\
\text { (Million rupiahs) }\end{array}$} \\
\hline Mean & 412317.2 & 177205 \\
\hline Min. & 2000 & 1000 \\
\hline Max. & 5670000 & 3000000 \\
\hline Std. & 872111.1 & 390397.3 \\
\hline \multicolumn{3}{|l|}{ RelatedLoans1 (\%) } \\
\hline Mean & 5.67 & 0.9 \\
\hline Min. & 0 & 0 \\
\hline Max. & 29.68 & 17.19 \\
\hline Std. & 7.36 & 2.38 \\
\hline Sample median & \multicolumn{2}{|c|}{0.30} \\
\hline
\end{tabular}

This table reports summary statistic by category of banks (state- or family-owned) on the number of loan announcements, the percentage of shares held by the largest shareholder, the percentage of shares held by minority shareholders, the size of loans, and the proportion of related loans. Banks are defined as state-owned or family-owned when their largest shareholder is the government, or a family, respectively. A minority shareholder holds less than $10 \%$ of shares. RelatedLoans 1 is the ratio of related loans to total loans. 
Table 3. Definitions, data sources and summary statistics for variables

\begin{tabular}{|c|c|c|c|c|c|c|}
\hline Variables & Definition & Data sources & Mean & $\begin{array}{l}\text { Standard } \\
\text { Deviation }\end{array}$ & Min. & Max. \\
\hline RelatedLoans1 & Related party loans to total loans & Annual Reports & 3.8 & 6.4 & 0 & 29 \\
\hline RelatedLoans2 & Related party loans to total assets & Annual Reports & 2.4 & 4.05 & 0 & 19.6 \\
\hline DLenderGvtOwned & $\begin{array}{l}\text { Takes the value of one for loan contracts when the lending bank is } \\
\text { state-owned, and zero otherwise }\end{array}$ & $\begin{array}{l}\text { Annual Reports } \\
\text { BvD Bankscope }\end{array}$ & 0.61 & 0.49 & 0 & 1 \\
\hline \multirow[t]{2}{*}{ DBorrowerGvtOwned } & $\begin{array}{l}\text { Takes the value of one for loan contracts when the borrower is } \\
\text { state-owned, and zero otherwise }\end{array}$ & Ministry of SOEs & & & & \\
\hline & & & 0.13 & 0.34 & 0 & 1 \\
\hline DLenderIndGvtOmwed & $\begin{array}{l}\text { Takes the value of one for loan contracts when the largest } \\
\text { shareholder is the government of Indonesia }\end{array}$ & $\begin{array}{l}\text { Annual Reports } \\
\text { BvD Bankscope }\end{array}$ & 0.49 & 0.50 & 0 & 1 \\
\hline DLenderForGvtOwned & $\begin{array}{l}\text { Takes the value of one for loan contracts when the largest } \\
\text { shareholder is a foreign government }\end{array}$ & $\begin{array}{l}\text { Annual Reports } \\
\text { BvD Bankscope }\end{array}$ & 0.12 & 0.33 & 0 & 1 \\
\hline DBorrowerPrivateInGroup & $\begin{array}{l}\text { Takes the value of one for loan contracts when the borrower is } \\
\text { privately-owned and belongs to a pyramidal business group }\end{array}$ & $\begin{array}{l}\text { IDX } \\
\text { Annual Reports } \\
\text { Websites }\end{array}$ & 0.81 & 0.39 & 0 & 1 \\
\hline DHighIndepDirectors & $\begin{array}{l}\text { Takes the value of one for loan contracts when the proportion of } \\
\text { independent commissioners is strictly higher than } 50 \%\end{array}$ & Annual Reports & 0.26 & 0.44 & 0 & 1 \\
\hline DLargeLoans & $\begin{array}{l}\text { Takes the value of one for loan contracts when the size of the loan } \\
\text { is above the median sample }\end{array}$ & Annual Reports & 0.49 & 0.50 & 0 & 1 \\
\hline DLenderGvtOwnedOnly & $\begin{array}{l}\text { Takes the value of one for a borrower with only state-owned banks } \\
\text { as lenders }\end{array}$ & $\begin{array}{l}\text { Annual Reports } \\
\text { BvD Bankscope }\end{array}$ & 0.38 & 0.49 & 0 & 1 \\
\hline DBothLender & $\begin{array}{l}\text { Takes the value of one for a borrower whose lenders are both state- } \\
\text { owned banks and family-owned banks }\end{array}$ & $\begin{array}{l}\text { Annual Reports } \\
\text { BvD Bankscope }\end{array}$ & 0.39 & 0.49 & 0 & 1 \\
\hline LoanSize & Amount of the loan to total asset of the borrowing firm & $\begin{array}{l}\text { Bloomberg and } \\
\text { Annual Reports }\end{array}$ & 14.05 & 67.70 & 0.01 & 91.54 \\
\hline TenureYear & Year number of loan maturity & Annual Reports & 3.01 & 2.31 & 0.5 & 10 \\
\hline InterestRate & Interest rate on loan & Annual Reports & 10.89 & 2.33 & 4 & 22 \\
\hline BorrowerROA & Net Income to total assets of the borrower & Bloomberg & 4.99 & 8.34 & -92.47 & 37.55 \\
\hline
\end{tabular}




\begin{tabular}{|c|c|c|c|c|c|c|}
\hline BorrowerLeverage & Total debt to total assets of the borrower & Bloomberg & 25.82 & 21.36 & 0 & 86.05 \\
\hline BorrowerSize & Logarithm of total assets of the borrower & Bloomberg & 14.68 & 1.69 & 10 & 18.53 \\
\hline LenderROA & Net income to total assets of the lending bank & Bloomberg & 4.92 & 0.97 & -3.20 & 2.88 \\
\hline LenderSize & Logarithm of total assets of the lending bank & Bloomberg & 18.76 & 1.47 & 14.84 & 20.41 \\
\hline LenderLeverage & Total equity to total assets of the lending bank & Bloomberg & 11.46 & 3.21 & 6.02 & 26 \\
\hline LenderOpacity & $\begin{array}{l}\text { Index of opacity. The first input into the index is the natural } \\
\text { logarithm of the average daily IDR volume during the fiscal year. } \\
\text { The second input is the bid-ask spread measured as the difference } \\
\text { between the ask and the bid price. We associate for each } \\
\text { component the value of one for the first decile, the value of two for } \\
\text { the second decile and so on. We then sum these two components } \\
\text { and we divide it by two to scale our composite index. It ranges in } \\
\text { principle from one to ten. }\end{array}$ & Bloomberg & 4.05 & 2.52 & 1 & 10 \\
\hline
\end{tabular}

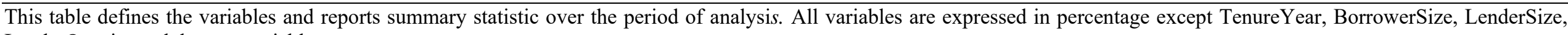
LenderOpacity and dummy variables. 
Table 4. Cumulative abnormal returns surrounding the loan announcement

\begin{tabular}{|c|c|c|c|c|}
\hline $\begin{array}{l}\text { Event windows } \\
\text { (Days) }\end{array}$ & Mean (\%) & $\begin{array}{l}\text { Wilcoxon Test } \\
\text { (z-probability) }\end{array}$ & $\begin{array}{c}\mathrm{t}-\text { Test } \\
\text { (t-statistic) }\end{array}$ & Observations \\
\hline \multicolumn{5}{|c|}{ Panel A: All Sample } \\
\hline$[-1,+1]$ & $-0,19$ & $0.01 * *$ & -1.19 & 342 \\
\hline$[-2,+2]$ & $-0,30$ & $0.01 * *$ & $-1.90^{*}$ & 342 \\
\hline$[-3,+3]$ & $-0,46$ & $0.00 * * *$ & $-2.26^{* *}$ & 342 \\
\hline \multicolumn{5}{|c|}{ Lenders with low levels of related loans } \\
\hline$[-1,+1]$ & $-0,09$ & 0.13 & -0.37 & 164 \\
\hline$[-2,+2]$ & $-0,4$ & $0.06^{*}$ & $-1.73 *$ & 164 \\
\hline$[-3,+3]$ & $-0,45$ & 0.13 & -1.32 & 164 \\
\hline \multicolumn{5}{|c|}{ Lenders with high levels of related loans } \\
\hline$[-1,+1]$ & $-0,27$ & $0.04 * *$ & -1.36 & 178 \\
\hline$[-2,+2]$ & $-0,20$ & 0.10 & -0.95 & 178 \\
\hline$[-3,+3]$ & $-0,48$ & $0.00 * * *$ & $-1.97 * *$ & 178 \\
\hline \multicolumn{5}{|c|}{ Panel B: State-owned banks } \\
\hline$[-1,+1]$ & -0.29 & $0.03 * *$ & -1.64 & 211 \\
\hline$[-2,+2]$ & -0.44 & $0.01 * *$ & $-2.32 * *$ & 211 \\
\hline$[-3,+3]$ & -0.45 & $0.05^{*}$ & $-1.80^{*}$ & 211 \\
\hline \multicolumn{5}{|c|}{ With low levels of related loans } \\
\hline$[-1,+1]$ & -0.49 & $0.04 * *$ & $-2.08 * *$ & 108 \\
\hline$[-2,+2]$ & -0.71 & $0.01 * *$ & $-2.62 * *$ & 108 \\
\hline$[-3,+3]$ & -0.55 & 0.20 & -1.46 & 108 \\
\hline \multicolumn{5}{|c|}{ With high levels of related loans } \\
\hline$[-1,+1]$ & -0.09 & 0.34 & -0.34 & 103 \\
\hline$[-2,+2]$ & -0.16 & 0.34 & -0.62 & 103 \\
\hline$[-3,+3]$ & -0.34 & 0.14 & -1.06 & 103 \\
\hline \multicolumn{5}{|c|}{ Panel C: Family-owned banks } \\
\hline$[-1,+1]$ & -0.01 & 0.17 & -0.05 & 131 \\
\hline$[-2,+2]$ & -0.05 & 0.34 & -0.22 & 131 \\
\hline$[-3,+3]$ & -0.48 & $0.02 * *$ & -1.37 & 131 \\
\hline \multicolumn{5}{|c|}{ With low levels of related loans } \\
\hline$[-1,+1]$ & 0.67 & 0.91 & 1.24 & 56 \\
\hline$[-2,+2]$ & 0.19 & 0.98 & 0.45 & 56 \\
\hline$[-3,+3]$ & -0.24 & 0.47 & -0.36 & 56 \\
\hline \multicolumn{5}{|c|}{ With high levels of related loans } \\
\hline$[-1,+1]$ & -0.53 & $0.05 *$ & $-1.74^{*}$ & 75 \\
\hline$[-2,+2]$ & -0.25 & 0.16 & -0.72 & 75 \\
\hline$[-3,+3]$ & -0.66 & $0.01 * *$ & $-1.83^{*}$ & 75 \\
\hline
\end{tabular}

This table reports the average Cumulative Abnormal Return (CARs) for loan announcements for different estimation windows on the overall sample (Panel A), for state-owned banks (Panel B) and for family-owned banks (Panel C). CARs are computed for the three event windows $[-1,+1],[-2,+2]$ and $[-3,+3]$. We use the sample median value of the lagged ratio related loans total loans (RelatedLoans1) to distinguish banks with relatively low and high levels of related loans. Significance of average CARs is tested with: (1) the Wilcoxon test (1945) that uses a median test of the null hypothesis to check if the mean return is not unduly influenced by outlier returns; and (2) the standard cross-sectional t-statistic that tests if the average CARs over any given time interval are equal to zero. The asterisks $(* * *),(* *)$ and $(*)$ denote significance at the $0.01,0.05$ and 0.1 levels, respectively. 
Table 5. Impact of government ownership of banks on cumulative abnormal returns

\begin{tabular}{|c|c|c|c|c|}
\hline & $\begin{array}{c}\text { CARs } \\
{[-2,+2]} \\
(1)\end{array}$ & $\begin{array}{c}\text { CARs } \\
{[-2,+2]} \\
(2)\end{array}$ & $\begin{array}{c}\text { CARs } \\
{[-2,+2]} \\
(3)\end{array}$ & $\begin{array}{c}\text { CARs } \\
{[-2,+2]} \\
(4)\end{array}$ \\
\hline RelatedLoans1 $\left(\beta_{1}\right)$ & $\begin{array}{l}-0.008 \\
(-0.38)\end{array}$ & $\begin{array}{c}-0.165^{* * *} \\
(-3.00)\end{array}$ & & \\
\hline RelatedLoans2 $\left(\beta_{1}\right)$ & & & $\begin{array}{l}-0.019 \\
(-0.58)\end{array}$ & $\begin{array}{c}-0.247^{* * *} \\
(-3.26)\end{array}$ \\
\hline RelatedLoans $1 *$ DLenderGvtOwned $\left(\beta_{2}\right)$ & & $\begin{array}{c}0.168^{* * *} \\
(2.89)\end{array}$ & & \\
\hline RelatedLoans2*DLenderGvtOwned $\left(\beta_{2}\right)$ & & & & $\begin{array}{c}0.244^{* * *} \\
(3.06)\end{array}$ \\
\hline DLenderGvtOwned & $\begin{array}{c}-0.007^{*} \\
(-2.06)\end{array}$ & $\begin{array}{c}-0.008^{* *} \\
(-2.47)\end{array}$ & $\begin{array}{l}-0.007^{*} \\
(-1.99)\end{array}$ & $\begin{array}{c}-0.008^{* *} \\
(-2.35)\end{array}$ \\
\hline LoanSize & $\begin{array}{l}-0.001 \\
(-0.52)\end{array}$ & $\begin{array}{l}-0.001 \\
(-0.53)\end{array}$ & $\begin{array}{l}-0.001 \\
(-0.52)\end{array}$ & $\begin{array}{l}-0.001 \\
(-0.53)\end{array}$ \\
\hline TenureYear & $\begin{array}{c}-0.001^{*} \\
(-1.80)\end{array}$ & $\begin{array}{l}-0.001^{*} \\
(-1.93)\end{array}$ & $\begin{array}{l}-0.001^{*} \\
(-1.80)\end{array}$ & $\begin{array}{l}-0.001^{*} \\
(-1.92)\end{array}$ \\
\hline InterestRate & $\begin{array}{l}-0.000 \\
(-0.08)\end{array}$ & $\begin{array}{l}-0.000 \\
(-0.13)\end{array}$ & $\begin{array}{l}-0.000 \\
(-0.06)\end{array}$ & $\begin{array}{l}-0.000 \\
(-0.09)\end{array}$ \\
\hline BorrowerROA & $\begin{array}{l}-0.000 \\
(-1.71)\end{array}$ & $\begin{array}{l}-0.000 \\
(-1.67)\end{array}$ & $\begin{array}{l}-0.000 \\
(-1.71)\end{array}$ & $\begin{array}{l}-0.000 \\
(-1.69)\end{array}$ \\
\hline BorrowerLeverage & $\begin{array}{c}-0.000^{* *} \\
(-2.33)\end{array}$ & $\begin{array}{c}-0.000^{* *} \\
(-2.38)\end{array}$ & $\begin{array}{c}-0.000^{* *} \\
(-2.33)\end{array}$ & $\begin{array}{c}-0.000^{* *} \\
(-2.38)\end{array}$ \\
\hline BorrowerSize & $\begin{array}{l}0.001 \\
(0.79)\end{array}$ & $\begin{array}{l}0.001 \\
(0.73)\end{array}$ & $\begin{array}{l}0.001 \\
(0.80)\end{array}$ & $\begin{array}{l}0.001 \\
(0.76)\end{array}$ \\
\hline LenderROA & $\begin{array}{l}0.003^{*} \\
(1.99)\end{array}$ & $\begin{array}{l}0.003^{*} \\
(2.02)\end{array}$ & $\begin{array}{l}0.003^{*} \\
(2.03)\end{array}$ & $\begin{array}{l}0.003^{*} \\
(2.03)\end{array}$ \\
\hline LenderLeverage & $\begin{array}{l}0.039 \\
(1.15)\end{array}$ & $\begin{array}{l}0.035 \\
(1.04)\end{array}$ & $\begin{array}{l}0.039 \\
(1.14)\end{array}$ & $\begin{array}{l}0.036 \\
(1.10)\end{array}$ \\
\hline LenderSize & $\begin{array}{l}0.001 \\
(0.50)\end{array}$ & $\begin{array}{l}0.001 \\
(0.36)\end{array}$ & $\begin{array}{l}0.001 \\
(0.50)\end{array}$ & $\begin{array}{l}0.001 \\
(0.38)\end{array}$ \\
\hline LenderOpacity & $\begin{array}{l}-0.001 \\
(-0.35)\end{array}$ & $\begin{array}{l}-0.000 \\
(-0.31)\end{array}$ & $\begin{array}{l}-0.001 \\
(-0.35)\end{array}$ & $\begin{array}{l}-0.000 \\
(-0.31)\end{array}$ \\
\hline Constant & $\begin{array}{l}-0.021 \\
(-0.43)\end{array}$ & $\begin{array}{l}-0.013 \\
(-0.27)\end{array}$ & $\begin{array}{l}-0.021 \\
(-0.43)\end{array}$ & $\begin{array}{l}-0.015 \\
(-0.30)\end{array}$ \\
\hline $\begin{array}{l}\text { Wald Tests } \\
\beta_{1}+\beta_{2}=0\end{array}$ & & $\begin{array}{c}-0.0025 \\
(-0.11) \\
\end{array}$ & & $\begin{array}{c}-0.0024 \\
(-0.07) \\
\end{array}$ \\
\hline $\begin{array}{l}\text { Nbr. Of obs. } \\
\text { Adjusted R-Squared }\end{array}$ & $\begin{array}{c}342 \\
0.0261\end{array}$ & $\begin{array}{c}342 \\
0.0319\end{array}$ & $\begin{array}{c}342 \\
0.0267\end{array}$ & $\begin{array}{c}342 \\
0.0316\end{array}$ \\
\hline $\begin{array}{l}\text { This table reports ordinary least square estimatio } \\
\text { loans and the type of banks (state- vs. family-c } \\
\text { valuation of banks by considering the likelihood } \\
\text { using family-owned banks as a benchmark agai } \\
\text { owned banks. Relatedloan1 is the ratio of relate } \\
\text { Relatedloan } 2 \text { is the ratio of related loan and total } \\
\text { contracts when the lending bank is state-owned, a } \\
\text { in parentheses, with *, } * * \text {, and } * * * \text { denoting sign }\end{array}$ & $\begin{array}{l}\text { C Cumulati } \\
\text { ed). We ex } \\
\text { expropriatio } \\
\text { which to as } \\
\text { ans to total } \\
\text { t. The dumi } \\
\text { zero otherwi } \\
\text { nce at } 10 \% \text {, }\end{array}$ & $\begin{array}{l}\text { ormal Retu } \\
\text { whether go } \\
\text { easured by } \\
\text { e valuation } \\
\text { CARs are } \\
\text { lable DLenc } \\
\text { l variables a } \\
\text { d } 1 \% \text { levels }\end{array}$ & $\begin{array}{l}\text { Rs) on the } \\
\text { it ownershi } \\
\text { ortance of } \\
\text { f loan anno } \\
\text { on the ev } \\
\text { whed takes } \\
\text { ed in Table }\end{array}$ & $\begin{array}{l}\text { ion of related } \\
\text { ts the market } \\
\text { loans, and by } \\
\text { ents for state- } \\
\text { dow }[-2,+2] \text {. } \\
\text { f one for loan } \\
\text { t-statistics are }\end{array}$ \\
\hline
\end{tabular}


Table 6. Impact of government ownership of banks on cumulative abnormal returns for different types of borrowing firms (state-owned versus privately-owned)

\begin{tabular}{|c|c|c|}
\hline & $\begin{array}{l}\text { CARs } \\
{[-2,+2]}\end{array}$ & $\begin{array}{l}\text { CARs } \\
{[-2,+2]}\end{array}$ \\
\hline RelatedLoan1 $\left(\alpha_{1}\right)$ & $\begin{array}{c}-0.163^{* * *} \\
(-3.03)\end{array}$ & \\
\hline RelatedLoan2 $\left(\alpha_{1}\right)$ & & $\begin{array}{c}-0.244^{* * *} \\
(-3.29)\end{array}$ \\
\hline RelatedLoan $1 *$ DBorrowerGvtOwned $\left(\alpha_{2}\right)$ & $\begin{array}{l}-0.154 \\
(-0.16)\end{array}$ & \\
\hline RelatedLoan $2 *$ DBorrowerGvtOwned $\left(\alpha_{2}\right)$ & & $\begin{array}{l}-0.502 \\
(-0.23)\end{array}$ \\
\hline RelatedLoan $1 *$ DLenderGvtOwned $\left(\alpha_{3}\right)$ & $\begin{array}{c}0.137^{* *} \\
(2.41)\end{array}$ & \\
\hline RelatedLoan $2 *$ DLenderGvtOwned $\left(\alpha_{3}\right)$ & & $\begin{array}{c}0.197^{* *} \\
(2.49)\end{array}$ \\
\hline RelatedLoan $1 *$ DLenderGvtOwned *DBorrowerGvtOwned $\left(\alpha_{4}\right)$ & $\begin{array}{l}0.317 \\
(0.33)\end{array}$ & \\
\hline RelatedLoan $2 *$ DLenderGvtOwned *DBorrowerGvtOwned $\left(\alpha_{4}\right)$ & & $\begin{array}{l}0.762 \\
(0.35)\end{array}$ \\
\hline DLenderGvtOwned *DBorrowerGvtOwned & $\begin{array}{c}-0.026^{* * *} \\
(-3.30)\end{array}$ & $\begin{array}{c}-0.026^{* * *} \\
(-3.29)\end{array}$ \\
\hline DLenderGvtOwned & $\begin{array}{l}-0.006 \\
(-1.64)\end{array}$ & $\begin{array}{l}-0.005 \\
(-1.53)\end{array}$ \\
\hline DBorrowerGvtOwned & $\begin{array}{l}0.011^{*} \\
(2.02)\end{array}$ & $\begin{array}{l}0.011^{*} \\
(2.04)\end{array}$ \\
\hline Constant & $\begin{array}{l}-0.019 \\
(-0.37)\end{array}$ & $\begin{array}{l}-0.020 \\
(-0.38)\end{array}$ \\
\hline Control variables & Yes & Yes \\
\hline $\begin{array}{l}\text { Nbr. Of obs. } \\
\text { Adjusted R-Squared }\end{array}$ & $\begin{array}{c}342 \\
0.033\end{array}$ & $\begin{array}{c}342 \\
0.032\end{array}$ \\
\hline
\end{tabular}

This table reports ordinary least square estimations of Cumulative Abnormal Returns (CARs) on the proportion of related loans, the type of banks (state- vs. family-owned), and the type of borrowers (state- vs privately-owned). We examine whether market reactions to loan announcements of state-owned banks in comparison to family-owned banks depend on the type of firms they lend to, by considering the likelihood of expropriation as measured by the importance of related loans. CARs are computed on the event window $[-2,+2]$. Relatedloan1 is the ratio of related loans to total loans. Relatedloan2 is the ratio of related loan and total asset. The dummy variable DLenderGvtOwned takes value of one for loan contracts when the lending bank is state-owned, and zero otherwise. The dummy variable DBorrowerGvtOwned takes value of one for loan contracts when the borrowing firms is state-owned, and zero otherwise. All variables are defined in Table 3 . The t-statistics are in parentheses, with $*, * *$, and $* * *$ denoting significance at $10 \%, 5 \%$ and $1 \%$ levels. 
Table 7. Impact of government ownership of banks on cumulative abnormal returns for different types of borrowing firms (state-owned versus privately-owned) : Wald tests from Table 6

\begin{tabular}{|c|c|c|}
\hline & RelatedLoan1 & RelatedLoan2 \\
\hline \multicolumn{3}{|c|}{ The lender is state-owned, the borrower is state-owned } \\
\hline$\alpha_{1}+\alpha_{2}+\alpha_{3}+\alpha_{4}=0$ & $\begin{array}{l}0.1370^{* * *} \\
\quad(3.78)\end{array}$ & $\begin{array}{l}0.2122 * * * \\
\quad(3.23)\end{array}$ \\
\hline \multicolumn{3}{|c|}{ The lender is state-owned, the borrower is privately-owned } \\
\hline & $\begin{array}{c}-0.0263 \\
(-1.18)\end{array}$ & $\begin{array}{c}-0.0477 \\
(-1.40)\end{array}$ \\
\hline
\end{tabular}

The lender is family-owned, the borrower is state-owned $\alpha_{1}+\alpha_{2}=0$

$$
\begin{array}{cc}
-0.3169 & -0.7468 \\
(-0.34) & (-0.35)
\end{array}
$$

The lender is family-owned, the borrower is privately-owned

$$
\begin{array}{ccc}
\alpha_{1}=0 & -0.1631^{* * *} & -0.2445^{* * *} \\
& (-3.03) & (-3.29)
\end{array}
$$

This table reports the Wald tests based on the regressions from Table 6. Relatedloan1 is the ratio of related loans to total loans. Relatedloan2 is the ratio of related loan and total asset. The t-statistics are in parentheses, with $* * *$, and $* * *$ denoting significance at $10 \%, 5 \%$ and $1 \%$ levels. 
Table 8. Extensions to analysis (1): government of Indonesia vs. foreign governments

\begin{tabular}{lcccc}
\hline $\begin{array}{l}\text { Event windows } \\
\text { (Days) }\end{array}$ & Mean (\%) & $\begin{array}{l}\text { Wilcoxon Test } \\
\text { (z-probability) }\end{array}$ & $\begin{array}{c}\text { t-Test } \\
\text { (t-statistic) }\end{array}$ & Observations \\
\hline
\end{tabular}

\section{Panel A: Indonesian state-owned banks}

With low levels of related loans

$[-1,+1]$

0.47

$-1.26$

65

$[-2,+2]$

$-0,4$

0.42

$-1.24$

65

$[-3,+3]$

$-0,3$

0.59

$-0.69$

65

With high levels of related loans

$[-1,+1]$

$-0,09$

0.34

$-0.34$

103

$[-2,+2]$

$-0,16$

0.34

$-0.62$

103

$[-3,+3]$

$-0,34$

0.14

$-1.06$

103

\section{Panel B: Foreign state-owned banks}

With low levels of related loans

$\begin{array}{lcccc}{[-1,+1]} & -0.66 & 0.03 * * & -1.70^{*} & 43 \\ {[-2,+2]} & -1.15 & 0.00^{* * *} & -2.58^{* *} & 43 \\ {[-3,+3]} & -0.91 & 0.19 & -1.40 & 43\end{array}$

With high levels of related loans

$[-1,+1]$

$[-2,+2]$

$-$

$-$

$-$

0

$[-3,+3]$

This table reports the average Cumulative Abnormal Return (CARs) for loan announcements for different estimation windows, for state-owned banks controlled by the government of Indonesia (Panel A), and for state-owned banks controlled by a foreign government (Panel B). CARs are computed for the three event windows $[-1,+1],[-2,+2]$ and $[-3,+3]$. We use the sample median value of the lagged ratio related loans total loans (RelatedLoans1) to distinguish banks with relatively low and high levels of related loans. Significance of average CARs is tested with: (1) the Wilcoxon test (1945) that uses a median test of the null hypothesis to check if the mean return is not unduly influenced by outlier returns; and (2) the standard cross-sectional t-statistic that tests if the average CARs over any given time interval are equal to zero. The asterisks $(* * *),(* *)$ and $(*)$ denote significance at the $0.01,0.05$ and 0.1 levels, respectively. 
Table 9. Extensions to analysis (1): government of Indonesia vs. foreign governments

\begin{tabular}{lcc}
\hline & CARs & CARs \\
& {$[-2,+2]$} & {$[-2,+2]$} \\
\hline RelatedLoan1 $\left(\beta_{1}\right)$ & $-0.168^{* * *}$ & \\
RelatedLoan2 $\left(\beta_{1}\right)$ & $-2.59)$ & $-0.251^{* * *}$ \\
& & $(-2.73)$ \\
RelatedLoan1* DLenderIndGvtOwned $\left(\beta_{2}\right)$ & $0.163^{* *}$ & \\
& $(2.36)$ & $0.236^{* *}$ \\
RelatedLoan2*DLenderIndGvtOwned $\left(\beta_{2}\right)$ & & $(2.38)$ \\
& & \\
RelatedLoan1*DLenderForGvtOwned $\left(\beta_{3}\right)$ & -2.617 & -4.269 \\
& $(-0.15)$ & $(-0.19)$ \\
RelatedLoan2*DLenderForGvtOwned $\left(\beta_{3}\right)$ & & -0.005 \\
& & $(-0.89)$ \\
DLenderIndGvtOwned & -0.005 & -0.009 \\
DLenderForGvtOwned & $(-0.98)$ & $(-0.86)$ \\
Constant & -0.009 & -0.026 \\
& $(-0.90)$ & $(-0.60)$ \\
Control variables & -0.024 & Yes \\
\hline Wald Tests & $(-0.56)$ & \\
$\beta_{1}+\beta_{2}=0$ & Yes & -0.015 \\
$\beta_{1}+\beta_{3}=0$ & & $(-0.39)$ \\
& -0.006 & -4.521 \\
Nbr. Of obs. & $(-0.22)$ & $(-0.20)$ \\
Adjusted R-Squared & -2.786 & 0.021 \\
& $(-0.22)$ & 342 \\
\end{tabular}

This table reports ordinary least square estimations of Cumulative Abnormal Returns (CARs) on the proportion of related loans, the type of banks (state-owned controlled by the government of Indonesia, state-owned controlled by a foreign government, and family-owned). We examine whether market reactions to loan announcements of state-owned banks in comparison to family-owned banks depend on the type of the controlling government (Indonesia vs. foreign), by considering the likelihood of expropriation as measured by the importance of related loans. CARs are computed on the event window $[-2,+2]$. Relatedloan1 is the ratio of related loans to total loans. Relatedloan2 is the ratio of related loan and total asset. The dummy variable DLenderIndGvtOwned takes value of one for loan contracts when the lending bank is state-owned and controlled by the government of Indonesia, and zero otherwise. The dummy variable DLenderIndForOwned takes value of one for loan contracts when the lending bank is state-owned and controlled by a foreign government, and zero otherwise. All variables are defined in Table 3. The t-statistics are in parentheses, with *, $* *$, and ${ }^{* * *}$ denoting significance at $10 \%, 5 \%$ and $1 \%$ levels 
Table 10. Extensions to analysis (2): type of the borrower (state-owned vs. privately-owned affiliated or not to a pyramidal business group)

\begin{tabular}{|c|c|c|}
\hline & $\begin{array}{l}\text { CARs } \\
{[-2,+2]}\end{array}$ & $\begin{array}{l}\text { CARs } \\
{[-2,+2]}\end{array}$ \\
\hline RelatedLoan $1(\alpha 1)$ & $\begin{array}{c}-10.595^{* * *} \\
(-3.54)\end{array}$ & \\
\hline RelatedLoan2 $(\alpha 1)$ & & $\begin{array}{c}-19.305^{* * *} \\
(-3.30)\end{array}$ \\
\hline RelatedLoan $1 *$ DBorrowerGvtOwned $(\alpha 2)$ & $\begin{array}{c}10.207^{* * *} \\
(3.01)\end{array}$ & \\
\hline RelatedLoan2*DBorrowerGvtOwned $(\alpha 2)$ & & $\begin{array}{l}18.597^{* *} \\
(2.73)\end{array}$ \\
\hline RelatedLoan $1 *$ DBorrowerPrivateInGroup $(\alpha 3)$ & $\begin{array}{c}10.448^{* * *} \\
(3.52)\end{array}$ & \\
\hline RelatedLoan $2 *$ DBorrowerPrivateInGroup $(\alpha 3)$ & & $\begin{array}{l}19.083^{* * *} \\
(3.27)\end{array}$ \\
\hline RelatedLoan $1 *$ DLenderGvtOwned $(\alpha 4)$ & $\begin{array}{c}10.531^{* * *} \\
(3.49)\end{array}$ & \\
\hline RelatedLoan2* DLenderGvtOwned $(\alpha 4)$ & & $\begin{array}{c}19.201^{* * *} \\
(3.26)\end{array}$ \\
\hline RelatedLoan $1 *$ DLenderGvtOwned *DBorrowerGvtOwned $(\alpha 5)$ & $\begin{array}{c}-10.012^{* * *} \\
(-2.93)\end{array}$ & \\
\hline RelatedLoan2* DLenderGvtOwned *DBorrowerGvtOwned $(\alpha 5)$ & & $\begin{array}{c}-18.291^{* *} \\
(-2.66)\end{array}$ \\
\hline RelatedLoan $1 *$ DLenderGvtOwned * DBorrowerPrivateInGroup $(\alpha 6)$ & $\begin{array}{c}-10.412^{* * *} \\
(-3.47)\end{array}$ & \\
\hline RelatedLoan2* DLenderGvtOwned * DBorrowerPrivateInGroup $(\alpha 6)$ & & $\begin{array}{c}-19.029^{* * *} \\
(-3.24)\end{array}$ \\
\hline DLenderGvtOwned * DBorrowerGvtOwned & $\begin{array}{l}-0.012 \\
(-0.43)\end{array}$ & $\begin{array}{l}-0.011 \\
(-0.37)\end{array}$ \\
\hline DLenderGvtOwned * DBorrowerPrivateInGroup & $\begin{array}{l}0.013 \\
(0.54)\end{array}$ & $\begin{array}{l}0.014 \\
(0.58)\end{array}$ \\
\hline DLenderGvtOwned & $\begin{array}{l}-0.020 \\
(-0.84)\end{array}$ & $\begin{array}{l}-0.021 \\
(-0.87)\end{array}$ \\
\hline DborrowerGvtOwned & $\begin{array}{l}-0.018 \\
(-1.05)\end{array}$ & $\begin{array}{l}-0.020 \\
(-1.05)\end{array}$ \\
\hline DBorrowerPrivateInGroup & $\begin{array}{l}-0.029^{*} \\
(-1.73)\end{array}$ & $\begin{array}{l}-0.031 \\
(-1.70)\end{array}$ \\
\hline Constant & $\begin{array}{l}0.013 \\
(0.24)\end{array}$ & $\begin{array}{l}0.013 \\
(0.24)\end{array}$ \\
\hline Control variables & Yes & Yes \\
\hline $\begin{array}{l}\text { Nbr. Of obs. } \\
\text { Adjusted R-Squared }\end{array}$ & $\begin{array}{c}342 \\
0.044\end{array}$ & $\begin{array}{c}342 \\
0.044\end{array}$ \\
\hline
\end{tabular}

This table reports ordinary least square estimations of Cumulative Abnormal Returns (CAR) on the proportion of related loans, the type of banks (state- vs. family-owned), and the type of borrowers (state-owned, privately-owned affiliated to a pyramidal business group, and privately-owned not affiliated to a pyramidal business group). We examine whether market reactions to loan announcements of state-owned banks in comparison to family-owned banks depend on the type of firms they lend to, by considering the likelihood of expropriation as measured by the importance of related loans. CARs are computed on the event window $[-2,+2]$. Relatedloan1 is the ratio of related loans to total loans. Relatedloan2 is the ratio of related loan and total asset. The dummy variable DLenderGvtOwned takes value of one for loan contracts when the lending bank is state-owned, and zero otherwise. The dummy variable DBorrowerGvtOwned takes value of one for loan contracts when the borrower is state-owned, and zero otherwise. The dummy variable DBorrowerPrivateInGroup takes value of one for loan contracts when the borrower is privately-owned and belongs to a pyramidal business group All variables are defined in Table 3. The t-statistics are in parentheses, with *, $* *$, and $* * *$ denoting significance at $10 \%, 5 \%$ and $1 \%$ levels. 
Table 11. Extensions to analysis (2): type of the borrower (state-owned vs. privately-owned affiliated or not to a pyramidal business group), Wald tests from Table 10

\begin{tabular}{lcc}
\hline & RelatedLoan1 & RelatedLoan2 \\
\hline The lender is state-owned, the borrower is state-owned & $0.1312 * * *$ & $0.2028^{* * *}$ \\
$\alpha_{1}+\alpha_{2}+\alpha_{4}+\alpha_{5}=0$ & $(3.77)$ & $(3.23)$ \\
The lender is state-owned, the borrower is privately-owned in a group & -0.0279 & -0.0502 \\
$\alpha_{1}+\alpha_{3}+\alpha_{4}+\alpha_{6}=0$ & $(-1.25)$ & $(-1.50)$ \\
The lender is state-owned, the borrower is privately-owned not in a group & -0.0640 & -0.1038 \\
$\alpha_{1}+\alpha_{4}=0$ & $(-0.63)$ & $(-0.66)$ \\
\hline The lender is family-owned, the borrower is state-owned & -0.3880 & -0.7075 \\
$\alpha_{1}+\alpha_{2}=0$ & $(-0.44)$ & $(-0.35)$ \\
The lender is family-owned, the borrower is privately-owned in a group & $-0.1467 * * *$ & $-0.2218^{* * *}$ \\
$\alpha_{1}+\alpha_{3}=0$ & $(-3.42)$ & $(-3.65)$ \\
The lender is family-owned, the borrower is privately-owned not in a group & $-10.5952^{* *}$ & $-19.3046^{* * *}$ \\
$\alpha_{1}=0$ & $(-3.54)$ & $(-3.30)$
\end{tabular}

This table reports the Wald tests based on the regressions from Table 10. Relatedloan1 is the ratio of related loans to total loans. Relatedloan 2 is the ratio of related loan and total asset. The t-statistics are in parentheses, with *,**, and *** denoting significance at $10 \%, 5 \%$ and $1 \%$ levels. 
Table 12. Extensions to analysis (3): proportion of independent directors on the board of banks

\begin{tabular}{lcc}
\hline & CARs & CARs \\
& {$[-2,+2]$} & {$[-2,+2]$} \\
\hline RelatedLoan1 & $-0.173^{* *}$ & $-0.247^{* *}$ \\
RelatedLoan2 & $(-2.11)$ & $(-2.21)$ \\
RelatedLoan1*DHighIndepDirectors & $0.174^{*}$ & \\
RelatedLoan2*DHighIndepDirectors & $(1.91)$ & $0.237^{*}$ \\
RelatedLoan1* DLenderGvtOwned & & $(1.84)$ \\
RelatedLoan2* DLenderGvtOwned & 0.00952 & \\
& $(0.07)$ & -0.0113 \\
RelatedLoan1* DLenderGvtOwned *DHighIndepDirectors & & $(-0.06)$ \\
& -0.00667 & \\
RelatedLoan2* DLenderGvtOwned *DHighIndepDirectors & $(-0.05)$ & 0.0272 \\
DLenderGvtOwned *DHighIndepDirectors & & $(0.13)$ \\
& & -0.00193 \\
DHighIndepDirectors & -0.00124 & $(-0.22)$ \\
& $(-0.14)$ & -0.000799 \\
DLenderGvtOwned & -0.00112 & $(-0.13)$ \\
Constant & $(-0.18)$ & -0.00661 \\
Control variables & -0.00723 & $(-1.18)$ \\
\hline Nbr. of obs. & $(-1.29)$ & -0.0181 \\
Adjusted R-Squared & -0.0157 & $(-0.42)$ \\
\end{tabular}

This table reports ordinary least square estimations of Cumulative Abnormal Returns (CARs) on the proportion of related loans, the type of banks (state- vs. family-owned), and the proportion of independent directors on their board. We examine whether market reactions to loan announcements of state-owned banks in comparison to family-owned banks depend on the proportion of independent directors on their board, by considering the likelihood of expropriation as measured by the importance of related loans. CARs are computed on the event window $[-2,+2]$. Relatedloan1 is the ratio of related loans to total loans. Relatedloan2 is the ratio of related loan and total asset. The dummy variable DLenderGvtOwned takes value of one for loan contracts when the lending bank is state-owned, and zero otherwise. The dummy variable DHighIndepDirectors takes value of one when the proportion of independent directors is strictly higher than $50 \%$, and zero otherwise. All variables are defined in Table 3 . The tstatistics are in parentheses, with $*, * *$, and $* * *$ denoting significance at $10 \%, 5 \%$ and $1 \%$ levels. 
Table 13. Extensions to analysis (3): proportion of independent directors on the board of banks, Wald tests based on Table 12

\begin{tabular}{lcc}
\hline & RelatedLoan1 & RelatedLoan2 \\
\hline State-owned banks, high independent directors & -0.004 & -0.006 \\
& $(-0.11)$ & $(-0.12)$ \\
State-owned banks, low independent directors & 0.011 & -0.009 \\
& $(0.03)$ & $(-0.16)$ \\
\hline Family-owned banks, high independent directors & $-0.173^{* *}$ & $-0.246^{* *}$ \\
& $(-2.11)$ & $(-2.21)$ \\
Family-owned banks, low independent directors & -0.163 & -0.258 \\
& $(-1.56)$ & $(-1.56)$ \\
\hline
\end{tabular}

This table reports the Wald tests based on the regressions from Table 12. Relatedloan1 is the ratio of related loans to total loans. Relatedloan2 is the ratio of related loan and total asset. The t-statistics are in parentheses, with $* * *$, and $* * *$ denoting significance at $10 \%, 5 \%$ and $1 \%$ levels. 
Table A1. Robustness check (1): CARs for alternative event-windows and tests for abnormal returns

\begin{tabular}{|c|c|c|c|c|c|c|}
\hline $\begin{array}{l}\text { Event } \\
\text { windows } \\
\text { (days) }\end{array}$ & Mean (\%) & $\begin{array}{l}\text { Wilcoxon Test } \\
\text { (z-probability) }\end{array}$ & $\begin{array}{c}\text { t-Test } \\
\text { (t-statistic) }\end{array}$ & $\begin{array}{c}\text { Patell Test } \\
\text { (z-probability) }\end{array}$ & $\begin{array}{l}\text { Boehmer Test } \\
\text { (z-probability) }\end{array}$ & Observations \\
\hline \multicolumn{7}{|l|}{ All Sample } \\
\hline$[-1,+1]$ & -0.18 & $0.012^{* *}$ & -1.19 & 0.174 & 0.271 & 342 \\
\hline$[-2 .+2]$ & -0.30 & $0.013^{* *}$ & $-1.90 *$ & 0.174 & 0.251 & 342 \\
\hline$[-3 .+3]$ & -0.46 & $0.004 * * *$ & $-2.26^{* *}$ & $0.088^{*}$ & 0.222 & 342 \\
\hline$[0 ;+1]$ & -0.26 & $0.001 * * *$ & $-2.06^{* *}$ & $0.007 * * *$ & $0.017^{* *}$ & 342 \\
\hline$[0 ;+2]$ & -0.35 & $0.006^{* * *}$ & $-2.59 * *$ & $0.002 * * *$ & $0.010^{* *}$ & 342 \\
\hline$[-1 ;+2]$ & -0.27 & $0.015^{* *}$ & $-1.75^{*}$ & 0.105 & 0.18 & 342 \\
\hline
\end{tabular}

This table reports the average Cumulative Abnormal Return (CARs) for loan announcements for the different alternative estimation windows $[-1,+1],[-2,+2],[-3,+3],[0,+1],[0,+2]$ and $[-1,+2]$ for the overall sample. We test the significance of average CARs using the Wilcoxon test (1945) that uses a median test of the null hypothesis to check if the mean return is not unduly influenced by outlier returns, and the standard cross-sectional t-statistic that tests if the average CARs over any given time interval are equal to zero. As the T-test is not immune to how abnormal returns are distributed across the event windows, we use alternatively both Pattel (1976) and Boehmer et al. (1991) tests that consider abnormal returns distribution, event-induced volatility and serial correlation to tackle this issue. The asterisks $(* * *),(* *)$ and $(*)$ denote significance at the $0.01,0.05$ and 0.1 levels, respectively. 
Table A2. Robustness check (1): alternative event-windows

\begin{tabular}{lccc}
\hline & CARs & CARs & CARs \\
& {$[-1,+2]$} & {$[0,+2]$} & {$[0,+1]$} \\
\hline RelatedLoan1 $(\alpha 1)$ & $-0.176^{*}$ & $-0.137^{* * *}$ & $-0.143^{* * *}$ \\
RelatedLoan1* DBorrowerGvtOwned $(\alpha 2)$ & $(-1.95)$ & $(-2.87)^{* * *}$ & $(-3.14)^{* * *}$ \\
& $-2.755^{* * *}$ & $-7.420^{* * *}$ & $-12.976^{* * *}$ \\
RelatedLoan1* DLenderGvtOwned $(\alpha 3)$ & $(-3.23)$ & $(-10.74)$ & $(-15.92)$ \\
& 0.150 & $0.145^{* * *}$ & $0.165^{* * *}$ \\
RelatedLoan1* DLenderGvtOwned * DBorrowerGvtOwned $(\alpha 4)$ & $(1.62)$ & $(2.84)$ & $(3.38)$ \\
& $2.926^{* * *}$ & $7.502^{* * *}$ & $13.021^{* * *}$ \\
DLenderGvtOwned* DBorrowerGvtOwned & $(3.46)$ & $(10.77)$ & $(15.93)$ \\
& $-0.033^{* * *}$ & $-0.035^{* * *}$ & $-0.068^{* * *}$ \\
DLenderGvtOwned & $(-5.45)$ & $(-5.73)$ & $(-11.97)$ \\
& -0.002 & $-0.005^{* *}$ & -0.004 \\
DBorrowerGvtOwned & $(-0.72)$ & $(-2.18)$ & $(-1.58)$ \\
Constant & $0.016 * *$ & $0.026^{* * *}$ & $0.066^{* * *}$ \\
Control variables & $(3.62)$ & $(6.90)$ & $(16.57)$ \\
Nbr. of obs. & -0.040 & 0.011 & 0.036 \\
Adjusted R-Squared & $(-0.78)$ & $(0.35)$ & $(0.86)$ \\
& Yes & Yes & Yes \\
\hline
\end{tabular}

This table reports ordinary least square estimations of Cumulative Abnormal Returns (CARs) on the proportion of related loans, the type of banks (state- vs. family-owned), and the type of borrowers (state- vs privately-owned). We examine whether market reactions to loan announcements of state-owned banks in comparison to family-owned banks depend on the type of firms they lend to, and on the event windows considered. CARs are computed on the event window $[-1,+2],[0,+2]$, and $[0,+1]$. Relatedloan 1 is the ratio of related loans to total loans. The dummy variable DLenderGvtOwned takes value of one for loan contracts when the lending bank is state-owned, and zero otherwise. The dummy variable DBorrowerGvtOwned takes value of one for loan contracts when the borrowing firms is state-owned, and zero otherwise. All variables are defined in Table 3. The t-statistics are in parentheses, with *, **, and *** denoting significance at $10 \%, 5 \%$ and $1 \%$ levels. 
Table A3. Robustness check (1): alternative event-windows, Wald tests based on Table A3

\begin{tabular}{|c|c|c|c|}
\hline & $\begin{array}{l}\text { CARs } \\
{[-1,+2]}\end{array}$ & $\begin{array}{l}\text { CARs } \\
{[0,+2]}\end{array}$ & $\begin{array}{l}\text { CARs } \\
{[0,+1]}\end{array}$ \\
\hline $\begin{array}{l}\text { The lender is state-owned, the borrower is state-owned } \\
\alpha_{1}+\alpha_{2}+\alpha_{3}+\alpha_{4}=0\end{array}$ & $\begin{array}{c}0.1456^{* * *} \\
(3.44)\end{array}$ & $\begin{array}{c}0.0898^{* *} \\
(2.01)\end{array}$ & $\begin{array}{c}0.0668 * * * \\
(3.13)\end{array}$ \\
\hline $\begin{array}{l}\text { The lender is state-owned, the borrower is privately-owned } \\
\alpha_{1}+\alpha_{3}=0\end{array}$ & $\begin{array}{l}-0.2597 \\
(-1.15)\end{array}$ & $\begin{array}{l}0.0078 \\
(0.52)\end{array}$ & $\begin{array}{l}0.0217 \\
(1.20)\end{array}$ \\
\hline $\begin{array}{l}\text { The lender is family-owned, the borrower is state-owned } \\
\alpha_{1}+\alpha_{2}=0\end{array}$ & $\begin{array}{c}-2.931 * * * \\
(-3.58)\end{array}$ & $\begin{array}{c}-7.5569 * * * \\
(-11.21)\end{array}$ & $\begin{array}{c}-14.2998 * * * \\
(-16.44)\end{array}$ \\
\hline $\begin{array}{l}\text { The lender is family-owned, the borrower is privately-owned } \\
\alpha_{1}=0\end{array}$ & $\begin{array}{r}-0.1762^{*} \\
(-1.95)\end{array}$ & $\begin{array}{c}-0.1372 * * * \\
(-2.87)\end{array}$ & $\begin{array}{c}-0.1430 * * * \\
(-3.14)\end{array}$ \\
\hline
\end{tabular}

This table reports the Wald tests based on the regressions from Table A3, when Cumulative Abnormal Returns (CARs) are computed on the event window $[-1,+2],[0,+2]$, and $[0,+1] .$. The t-statistics are in parentheses, with *, **, and *** denoting significance at $10 \%, 5 \%$ and $1 \%$ levels. 
Table A4. Robustness check (2): size of loans

\begin{tabular}{lcc}
\hline & CARs & CARs \\
& {$[-2,+2]$} & {$[-2,+2]$} \\
\hline RelatedLoan1 & $-0.174^{* *}$ & \\
RelatedLoan2 & $(-2.12)$ & $-0.271^{* *}$ \\
& & $(-2.22)$ \\
RelatedLoan1*DLargeLoan & 0.005 & \\
RelatedLoan2*DLargeLoan & $(0.05)$ & 0.042 \\
RelatedLoan1*DLenderGvtOwned*DLargeLoan & & $(0.30)$ \\
& & \\
RelatedLoan2*DLenderGvtOwned*DLargeLoan & $(0.19)$ & \\
& & 0.004 \\
RelatedLoan1*DLenderGvtOwned & & $(0.03)$ \\
RelatedLoan2*DLenderGvtOwned & $0.168^{*}$ & \\
& $(1.91)$ & $0.256^{*}$ \\
DLenderGvtOwned*DLargeLoan & & $(1.93)$ \\
DLenderGvtOwned & -0.001 \\
DLargeLoan & -0.001 & $(-0.12)$ \\
Constant & $(-0.10)$ & -0.007 \\
Control variables & -0.007 & $(-1.19)$ \\
Nbr. of obs. & $(-1.26)$ & 0.008 \\
Adjusted R-Squared & 0.008 & $(1.26)$ \\
\hline & $(1.25)$ & 0.020 \\
& 0.021 & $(0.48)$ \\
& $(0.51)$ & 342 \\
& Yes & 0.028 \\
\hline
\end{tabular}

This table reports ordinary least square estimations of Cumulative Abnormal Returns (CARs) on the proportion of related loans, the type of banks (state- vs. family-owned), and the size of the loan. We examine whether market reactions to loan announcements of state-owned banks in comparison to family-owned banks depend on the size of the loan. CARs are computed on the event window $[-2,+2]$. Relatedloan1 is the ratio of related loans to total loans. Relatedloan2 is the ratio between related loan and total asset. The dummy variable DLenderGvtOwned takes value of one for loan contracts when the lending bank is state-owned, and zero otherwise. The dummy variable DLargeLoan takes the value of one for loan contracts when the size of the loan is above the median sample. All variables are defined in Table 3. The t-statistics are in parentheses, with *, **, and ${ }^{* * *}$ denoting significance at $10 \%, 5 \%$ and $1 \%$ levels. 
Table A5. Robustness check (2); size of loans, Wald tests based on Table A5

\begin{tabular}{lll}
\hline & RelatedLoan1 & RelatedLoan2 \\
\hline State-owned banks, Large Loans & 0.021 & 0.031 \\
State-owned banks, Smaller Loans & $(0.56)$ & $(0.48)$ \\
& -0.005 & -0.016 \\
\hline Family-owned banks, Large Loans & $(-0.16)$ & $(-0.31)$ \\
& $-0.168^{* *}$ & $-0.229^{* *}$ \\
Family-owned banks, Smaller Loans & $(-2.59)$ & $(-2.57)$ \\
& $-0.174^{* *}$ & $-0.271^{* *}$ \\
\hline
\end{tabular}

This table reports the Wald tests based on the regressions from Table A5. Relatedloan1 is the ratio of related loans to total loans. Relatedloan2 is the ratio of related loan and total asset. The t-statistics are in parentheses, with $*, * *$, and $* * *$ denoting significance at $10 \%, 5 \%$ and $1 \%$ levels. 
Table A6. Robustness check (3): several lenders to the same firm over time

\begin{tabular}{|c|c|c|}
\hline & $\begin{array}{l}\text { CARs } \\
{[-2,+2]}\end{array}$ & $\begin{array}{l}\text { CARs } \\
{[-2,+2]}\end{array}$ \\
\hline RelatedLoan1 $\left(\beta_{1}\right)$ & $\begin{array}{c}-0.165^{* * *} \\
(-5.35)\end{array}$ & \\
\hline RelatedLoan2 $\left(\beta_{1}\right)$ & & $\begin{array}{c}-0.253^{* * *} \\
(-5.45)\end{array}$ \\
\hline RelatedLoan $1 *$ DLenderGvtOwnedOnly $\left(\beta_{2}\right)$ & $\begin{array}{c}0.130^{* * *} \\
(3.15)\end{array}$ & \\
\hline RelatedLoan2*DLenderGvtOwnedOnly $\left(\beta_{3}\right)$ & & $\begin{array}{c}0.190^{* * *} \\
(3.15)\end{array}$ \\
\hline RelatedLoan $1 *$ DBothLenders & $\begin{array}{c}0.193^{* * *} \\
(4.98)\end{array}$ & \\
\hline RelatedLoan $2 *$ DBothLenders & & $\begin{array}{c}0.295^{* * *} \\
(4.81)\end{array}$ \\
\hline DLenderGvtOwnedOnly & $\begin{array}{c}-0.00410 \\
(-0.97)\end{array}$ & $\begin{array}{c}-0.00372 \\
(-0.88)\end{array}$ \\
\hline Both & $\begin{array}{c}-0.00420 \\
(-1.12)\end{array}$ & $\begin{array}{c}-0.00402 \\
(-1.08)\end{array}$ \\
\hline Constant & $\begin{array}{c}0.000505 \\
(0.01) \\
\end{array}$ & $\begin{array}{c}0.000300 \\
(0.01) \\
\end{array}$ \\
\hline Wald Tests & & \\
\hline$\beta_{1}+\beta_{2}=0$ & $\begin{array}{l}-0.0346 \\
(-1.08)\end{array}$ & $\begin{array}{l}-0.0627 \\
(-1.34)\end{array}$ \\
\hline$\beta_{1}+\beta_{3}=0$ & $\begin{array}{c}0.0286 \\
(1.18) \\
\end{array}$ & $\begin{array}{r}0.0423 \\
(1.08) \\
\end{array}$ \\
\hline $\begin{array}{l}\text { Nbr. of obs. } \\
\text { Adjusted R-Squared }\end{array}$ & $\begin{array}{c}342 \\
0.0251 \\
\end{array}$ & $\begin{array}{c}342 \\
0.0260\end{array}$ \\
\hline
\end{tabular}

This table reports ordinary least square estimations of Cumulative Abnormal Returns (CARs) on the proportion of related loans, the type of the lender (state- vs. family-owned), and the borrowing firms' decision to borrow only from state-owned bank or using both state-owned bank and family banks over the period of analysis. We examine whether market reactions to loan announcements of state-owned banks in comparison to family-owned banks depend on the other loan contracts the borrower have with family-owned banks. CARs are computed on the event window $[-2,+2]$. Relatedloan 1 is the ratio of related loans to total loans. Relatedloan2 is the ratio between related loan and total asset. The dummy variable DLenderGvtOwnedOnly takes the value of one for a borrower with only state-owned banks as lenders. The dummy variable DBothLender takes the value of one for a borrower whose lenders are both state-owned banks and family-owned banks. All variables are defined in Table 3. The t-statistics are in parentheses, with $*, * *$, and $* * *$ denoting significance at $10 \%, 5 \%$ and $1 \%$ levels. 
Table A7. Robustness check (4): exclusion of local governments from state-owned banks

\begin{tabular}{|c|c|c|}
\hline & $\begin{array}{c}\text { CAR } \\
{[-2,+2]}\end{array}$ & $\begin{array}{c}\text { CAR } \\
{[-2,+2]}\end{array}$ \\
\hline RelatedLoan1 $\left(\beta_{1}\right)$ & $\begin{array}{c}-0.159^{* * *} \\
(-2.61)\end{array}$ & \\
\hline RelatedLoan2 $\left(\beta_{1}\right)$ & & $\begin{array}{c}-0.238^{* * *} \\
(-2.73)\end{array}$ \\
\hline RelatedLoan $1 *$ DLenderGvtOwned $\left(\beta_{2}\right)$ & $\begin{array}{l}0.169^{* *} \\
(2.54)\end{array}$ & \\
\hline RelatedLoan $2 *$ DLenderGvtOwned $\left(\beta_{2}\right)$ & & $\begin{array}{c}0.248^{* *} \\
(2.56)\end{array}$ \\
\hline DLenderGvtOwned & $\begin{array}{c}-0.009^{* *} \\
(-2.31)\end{array}$ & $\begin{array}{c}-0.009^{* *} \\
(-2.22)\end{array}$ \\
\hline LoanSize & $\begin{array}{l}-0.001 \\
(-0.55)\end{array}$ & $\begin{array}{l}-0.001 \\
(-0.56)\end{array}$ \\
\hline TenureYear & $\begin{array}{l}-0.001 \\
(-1.50)\end{array}$ & $\begin{array}{l}-0.001 \\
(-1.49)\end{array}$ \\
\hline InterestRate & $\begin{array}{l}-0.000 \\
(-0.18)\end{array}$ & $\begin{array}{l}-0.000 \\
(-0.15)\end{array}$ \\
\hline BorrowerROA & $\begin{array}{l}-0.000 \\
(-1.42)\end{array}$ & $\begin{array}{l}-0.000 \\
(-1.43)\end{array}$ \\
\hline BorrowerLeverage & $\begin{array}{c}-0.000^{* *} \\
(-2.46)\end{array}$ & $\begin{array}{c}-0.000^{* *} \\
(-2.47)\end{array}$ \\
\hline BorrowerSize & $\begin{array}{l}0.001 \\
(0.58)\end{array}$ & $\begin{array}{l}0.001 \\
(0.61)\end{array}$ \\
\hline LenderROA & $\begin{array}{l}0.003 \\
(1.36)\end{array}$ & $\begin{array}{l}0.003 \\
(1.37)\end{array}$ \\
\hline LenderLeverage & $\begin{array}{l}0.018 \\
(0.35)\end{array}$ & $\begin{array}{l}0.020 \\
(0.40)\end{array}$ \\
\hline LenderSize & $\begin{array}{l}0.001 \\
(0.67)\end{array}$ & $\begin{array}{l}0.001 \\
(0.68)\end{array}$ \\
\hline LenderOpacity & $\begin{array}{l}-0.000 \\
(-0.28)\end{array}$ & $\begin{array}{l}-0.000 \\
(-0.29)\end{array}$ \\
\hline Constant & $\begin{array}{l}-0.020 \\
(-0.49)\end{array}$ & $\begin{array}{l}-0.021 \\
(-0.51)\end{array}$ \\
\hline $\begin{array}{l}\text { Wald Test } \\
\beta_{1}+\beta_{2}=0\end{array}$ & $\begin{array}{l}0.101 \\
(0.40)\end{array}$ & $\begin{array}{l}0.010 \\
(0.24)\end{array}$ \\
\hline $\begin{array}{l}\text { Nbr. Of obs. } \\
\text { Adjusted R-Squared }\end{array}$ & $\begin{array}{c}336 \\
0.022\end{array}$ & $\begin{array}{c}336 \\
0.022\end{array}$ \\
\hline
\end{tabular}

This table reports ordinary least square estimations of Cumulative Abnormal Returns (CARs) on the proportion of related loans and the type of banks (state- vs. family-owned) when we exclude state-owned banks controlled by local governments. CARs are computed on the event window $[-2,+2]$. Relatedloan1 is the ratio of related loans to total loans. Relatedloan2 is the ratio of related loan and total asset. The dummy variable DLenderGvtOwned takes value of one for loan contracts when the lending bank is state-owned, and zero otherwise. The dummy variable All variables are defined in Table 3. The t-statistics are in parentheses, with *, $* *$, and $* * *$ denoting significance at $10 \%, 5 \%$ and $1 \%$ levels. 
Table A8. Robustness check (4): exclusion of local governments from state-owned banks

\begin{tabular}{|c|c|c|}
\hline & $\begin{array}{l}\text { CARs } \\
{[-2,+2]}\end{array}$ & $\begin{array}{l}\text { CARs } \\
{[-2,+2]}\end{array}$ \\
\hline RelatedLoan1 $\left(\alpha_{1}\right)$ & $\begin{array}{c}-0.158^{* * *} \\
(-2.95)\end{array}$ & \\
\hline RelatedLoan2 $\left(\alpha_{1}\right)$ & & $\begin{array}{c}-0.237^{* * *} \\
(-3.20)\end{array}$ \\
\hline RelatedLoan $1 *$ DBorrowerGvtOwned $\left(\alpha_{2}\right)$ & $\begin{array}{l}-0.115 \\
(-0.12)\end{array}$ & \\
\hline RelatedLoan $2 *$ DBorrowerGvtOwned $\left(\alpha_{2}\right)$ & & $\begin{array}{l}-0.406 \\
(-0.19)\end{array}$ \\
\hline RelatedLoan $1 *$ DLenderGvtOwned $\left(\alpha_{3}\right)$ & $\begin{array}{l}0.139^{* *} \\
(2.46)\end{array}$ & \\
\hline RelatedLoan $2 *$ DLenderGvtOwned $\left(\alpha_{3}\right)$ & & $\begin{array}{c}0.201^{* *} \\
(2.55)\end{array}$ \\
\hline RelatedLoan $1 *$ DLenderGvtOwned *DBorrowerGvtOwned $\left(\alpha_{4}\right)$ & $\begin{array}{l}0.278 \\
(0.29)\end{array}$ & \\
\hline RelatedLoan2* DLenderGvtOwned *DBorrowerGvtOwned $\left(\alpha_{4}\right)$ & & $\begin{array}{l}0.666 \\
(0.30)\end{array}$ \\
\hline DLenderGvtOwned *DborrowerGvtOwned & $\begin{array}{c}-0.025^{* * *} \\
(-3.12)\end{array}$ & $\begin{array}{c}-0.025^{* * *} \\
(-3.11)\end{array}$ \\
\hline DLenderGvtOwned & $\begin{array}{l}-0.007^{*} \\
(-1.92)\end{array}$ & $\begin{array}{l}-0.006^{*} \\
(-1.81)\end{array}$ \\
\hline DBorrowerGvtOwned & $\begin{array}{l}0.010^{*} \\
(1.80)\end{array}$ & $\begin{array}{l}0.010^{*} \\
(1.82)\end{array}$ \\
\hline Constant & $\begin{array}{l}-0.024 \\
(-0.46)\end{array}$ & $\begin{array}{l}-0.025 \\
(-0.48)\end{array}$ \\
\hline Control variables & Yes & Yes \\
\hline $\begin{array}{l}\text { Nbr. Of obs. } \\
\text { Adjusted R-Squared }\end{array}$ & $\begin{array}{c}336 \\
0.030\end{array}$ & $\begin{array}{c}336 \\
0.029\end{array}$ \\
\hline
\end{tabular}

This table reports ordinary least square estimations of Cumulative Abnormal Returns (CARs) on the proportion of related loans, the type of banks (state- vs. family-owned), and the type of borrowers (state- vs privately-owned) when we exclude state-owned banks controlled by local governments. CARs are computed on the event window $[-2,+2]$. Relatedloan 1 is the ratio of related loans to total loans. Relatedloan2 is the ratio of related loan and total asset. The dummy variable DLenderGvtOwned takes value of one for loan contracts when the lending bank is state-owned, and zero otherwise. The dummy variable DBorrowerGvtOwned takes value of one for loan contracts when the borrowing firms is state-owned, and zero otherwise. All variables are defined in Table 3. The t-statistics are in parentheses, with *, **, and *** denoting significance at $10 \%, 5 \%$ and $1 \%$ levels. 
Table A9. Robustness check (4): exclusion of local governments from state-owned banks, Wald test based on Table A9

\begin{tabular}{|c|c|c|}
\hline & RelatedLoan1 & RelatedLoan2 \\
\hline \multicolumn{3}{|c|}{ The lender is state-owned, the borrower is state-owned } \\
\hline$\alpha_{1}+\alpha_{2}+\alpha_{3}+\alpha_{4}=0$ & $\begin{array}{l}0.1436^{* * *} \\
(4.08)\end{array}$ & $\begin{array}{l}0.2231 * * * \\
(3.47)\end{array}$ \\
\hline \multicolumn{3}{|c|}{ The lender is state-owned, the borrower is privately-owned } \\
\hline & $\begin{array}{c}-0.1923 \\
(-0.86)\end{array}$ & $\begin{array}{c}-0.0365 \\
(-1.07)\end{array}$ \\
\hline
\end{tabular}

The lender is family-owned, the borrower is state-owned $\alpha_{1}+\alpha_{2}=0$

$$
\begin{array}{r}
-0.2730 \\
(-0.29)
\end{array}
$$

The lender is family-owned, the borrower is privately-owned

$$
\begin{array}{ccc}
\alpha_{1}=0 & -0.1580 * * * & -0.2370 * * * \\
& (-2.95) & (-3.20)
\end{array}
$$

This table reports the Wald tests based on the regressions from Table A9. Relatedloan1 is the ratio of related loans to total loans. Relatedloan2 is the ratio of related loan and total asset. The t-statistics are in parentheses, with $* * *$, and $* * *$ denoting significance at $10 \%, 5 \%$ and $1 \%$ levels. 